\title{
Oct-4 $4^{+} /$Tenascin $\mathrm{C}^{+}$neuroblastoma cells serve as progenitors of tumor-derived endothelial cells
}

Annalisa Pezzolo ${ }^{1}$, Federica Parodi ${ }^{1}$, Danilo Marimpietri ${ }^{1}$, Lizzia Raffaghello ${ }^{1}$, Claudia Cocco ${ }^{2}$, Angela Pistorio ${ }^{3}$, Manuela Mosconi ${ }^{4}$, Claudio Gambini ${ }^{4}$, Michele Cilli ${ }^{5}$, Silvia Deaglio ${ }^{6}$, Fabio Malavasi ${ }^{6}$, Vito Pistoia ${ }^{1}$

${ }^{1}$ Laboratory of Oncology; ${ }^{2}$ AIRC Tumor Immunology Unit; ${ }^{3}$ Epidemiology and Biostatistics Unit, Istituto Giannina Gaslini, Largo G. Gaslini 5, 16147 Genova-Quarto, Italy; ${ }^{4}$ Laboratory of Pathology, Department of Experimental and Laboratory Medicine, IRCCS G. Gaslini Hospital, Genova, Italy; ${ }^{5}$ Animal Research Facility, National Cancer Institute, Genova, Italy; ${ }^{6}$ Department of Genetics, Biology and Biochemistry, University of Torino, Torino, Italy

Neuroblastoma (NB)-associated endothelial microvessels (EMs) may be lined by tumor-derived endothelial cells (TECs), that are genetically unstable and chemoresistant. Here we have addressed the identification of TEC progenitors in NB by focusing on Octamer-binding transcription factor 4 (Oct-4) as a putative marker. Oct- $4^{+}$cells were detected in primary NB samples $(n=23)$, metastatic bone marrow aspirates $(n=10)$, NB cell lines $(n=4)$, and orthotopic tumors $(n=10)$ formed by the HTLA-230 NB cell line in immunodeficient mice. Most Oct- $4^{+}$cells showed a perivascular distribution, with $5 \%$ of them homing in perinecrotic areas. All Oct- $4^{+}$cells were tumor-derived since they shared amplification of $M Y C N$ oncogene with malignant cells. Perivascular Oct- $4^{+}$cells expressed stem cellrelated, neural progenitor-related and NB-related markers, including surface Tenascin $C$ (TNC), that was absent from perinecrotic Oct- $4^{+}$cells and bulk tumor cells. $\mathrm{TNC}^{+}$but not $\mathrm{TNC}^{-} \mathrm{HTLA}-230$ cells differentiated in vitro into endothelial-like cells expressing vascular-endothelial-cadherin, prostate-specific membrane antigen and CD31 upon culture in medium containing vascular endothelial growth factor (VEGF). TNC $^{+}$but not TNC $^{-}$HTLA-230 cells formed neurospheres when cultured in serum-free medium. Both cell fractions were tumorigenic, but only tumors formed by $\mathrm{TNC}^{+}$cells contained EMs lined by TECs. In conclusion, we have identified in NB tumors two putative niches containing Oct $-4^{+}$tumor cells. Oct $-4^{+} / \mathrm{TNC}^{+}$perivascular $\mathrm{NB}$ cells displayed a high degree of plasticity and served as progenitors of TECs. Therapeutic targeting of $\mathrm{Oct}^{+} / \mathrm{TNC}^{+}$progenitors may counteract the contribution of NB-derived ECs to tumor relapse and chemoresistance.

Keywords: neuroblastoma; vascular mimicry; tumor-derived endothelium; progenitor cells; Tenascin C Cell Research (2011) 21:1470-1486. doi:10.1038/cr.2011.38; published online 15 March 2011

\section{Introduction}

Neuroblastoma (NB) is a tumor derived from primitive cells of the sympathetic nervous system and is the second most common solid tumor in childhood [1]. Approximately a half of NB patients present with metastatic disease at diagnosis, and only one-third of them survive at 5 years. About $22 \%$ of the NB tumors show amplification of the myelocytomatosis viral related oncogene NB-

Correspondence: Annalisa Pezzolo

Tel: +39-010-5636342; Fax: +39-010-3779820

E-mail: annalisapezzolo@ospedale-gaslini.ge.it

Received 29 August 2010; revised 7 December 2010; accepted 10 January 2011; published online 15 March 2011 derived $(M Y C N)[1]$.

Tumor growth is critically dependent on adequate blood supply provided by newly formed endothelial microvessels (EMs). Strong correlations have been established in different malignancies between high degree of tumor vascularization and unfavorable outcome [2-6].

Endothelial precursors are recruited to form tumor neo-vessels through a phenomenon known as "angiogenic switch" and dependent on the production of pro-angiogenic factors (e.g., VEGF) by tumor cells [4-6]. There is debate as to the respective contribution of bone marrow (BM)-derived vs local endothelial precursors to tumor neo-angiogenesis. An additional pathway of tumor-associated EM generation is represented by the so-called vascular mimicry [7], whereby cancer cells are incorporated 
in vascular structures where they may acquire features typical of "professional" endothelial cells (ECs) [8-11].

We previously demonstrated that primary NB-associated EM may be lined by TECs and, accordingly, TEClined EMs were identified in tumors formed in immunodeficient mice by human $M Y C N$ amplified [8] and $M Y C N$ non-amplified [10] NB cell lines.

The Octamer-binding transcription factor 4 (Oct-4), together with SOX-2 and NANOG, maintains self-renewal and blocks cell differentiation in embryonic stem cells [12-14] and is expressed by some cancer stem cells [15-20]. Among these factors, Oct-4 and SOX-2 appear to be indispensable for stemness maintenance [21]. Previous studies have demonstrated that Oct-4 is expressed by side-population cells and tumor-initiating cells from human NB, indicating that Oct- $4^{+} \mathrm{NB}$ cells include tumor stem/progenitor cells [20, 22].

In this study we have investigated whether Oct-4 is a marker of NB cells acting as TEC progenitors. Both primary and metastatic NB cells as well as NB cell lines were found to express Oct-4. Tenascin C (TNC), a protein of the extracellular matrix expressed by many tumor cell types and involved in tumor growth, metastasis and angiogenesis [23-29], was consistently expressed on the surface of most Oct- $4^{+} \mathrm{NB}$ cells but not of bulk tumor cells. The availability of TNC as a surface marker allowed one to positively select Oct- $4^{+} \mathrm{NB}$ cells to perform functional studies proving that $\mathrm{Oct}-4^{+} / \mathrm{TNC}^{+}$cells serve as TEC progenitors.

\section{Results}

Identification of Oct- $4^{+}$cells in primary NB samples and $N B$ cell lines

Primary NB tissue sections from 23 patients at different disease stages were tested for Oct-4A isoform expression by immunofluorescence. Oct-4A is specifically involved in stemness maintenance, is highly expressed in human embryonic stem cells and downregulated following differentiation [30]. Oct-4A, together with SOX-2 and NANOG, governs the transcriptional regulatory network by activating expression of pluripotency-related genes and repressing expression of differentiation-related genes [30]. Oct-4A protein is usually localized in the nucleus as a transcription factor. However, Wang et al. [31] found that Oct-4A protein was diffusely localized in both cytoplasm and nucleus.

In all, 21 out of 23 tumor samples were found to contain $2-30 \%$ Oct-4A (henceforth referred to as Oct-4) positive cells (Table 1 ). Most Oct- $4^{+}$cells were detected in perivascular spaces (Figure 1A, 1), consistent with the selective homing of normal stem cells $[32,33]$ and some cancer stem cells to perivascular niches [34-36]. A small minority of Oct $-4^{+}$cells (approximately $5 \%$ ) were identified in perinecrotic areas (Figure 1A, 2). All Oct- $4^{+}$cells displayed granular cytoplasmic (Golgi-like) and punctate nuclear staining patterns (Figure 1A-1D), in accordance with other studies in bladder, prostate and lung cancers [37-39].

In order to demonstrate the neoplastic origin of Oct- $4^{+}$ cells, seven $M Y C N$-amplified NB tumors were tested by combining immunofluorescence with FISH (Table 1, cases \#4, 18-23). Oct- $4^{+}$cells showed MYCN amplification as double minutes, indicating that these cells were tumor-derived (Figure 1A, 3 and 4). No correlation was found between the proportion of Oct- $4^{+}$cells and tumor stage, patient age or $M Y C N$ amplification.

Cytospins from metastatic BM aspirates of 10 patients with stage $4 \mathrm{NB}$ (range $10-80 \% \mathrm{NB} 84^{+}$cells) were stained for Oct-4 by immunofluorescence (Figure 1B). Oct- $4^{+}$cells were detected in all samples (Table 1). Next, these aspirates were double stained with anti-Oct- 4 and anti-NB84 (an NB-specific marker) mAbs [40, 41]. All BM Oct- $4^{+}$cells co-expressed NB84 (range 0.2-1.5\%), thus proving their tumor origin (Table 1 and Figure 1B).

Three MYCN amplified (HTLA-230, GI-LI-N and LAN-5) and two MYCN non-amplified (SHSY-5Y and ACN) human NB cell lines were also tested for Oct-4 expression. HTLA-230, SHSY-5Y, LAN-5 and ACN cell lines, but not GI-LI-N cells, expressed Oct-4 (range $2-15 \%$ ) with a predominant nuclear staining pattern (Figure 1C).

Identification and immunophenotypic characterization of Oct- $4^{+}$tumor cells in an orthotopic mouse model of human $N B$

In subsequent experiments, HTLA-230 cells were injected in the adrenal gland capsule of nude mice to generate orthotopic tumors recapitulating the natural history of primary human NB [42]. The choice of the HTLA230 cell model was based on previous studies from our group showing that these $M Y C N$-amplified cells formed metastatic tumors containing TEC-lining EM [8]. In analogy to that observed with primary NB, 10 orthotopic tumors were found to contain Oct- $4^{+}$cells predominantly in perivascular spaces $(16.8 \% \pm 2 \%)$ (Figure $1 \mathrm{D}, 1$ and 2 ), with a small subset of them homing in perinecrotic areas $(4 \% \pm 2 \%)$ (Figure 1D, 3). All Oct- $4^{+}$cells harbored $M Y C N$ amplification, indicating that they were tumorderived (Figure 1D, 4).

Oct $-4^{+}$cells did not express the human EC marker CD31 (hCD31) (Figure 1D, 1) or the pericyte marker $\alpha$-SMA (Figure 1D, 2) and adhered or homed in close proximity to $\alpha-\mathrm{SMA}^{+}$pericytes coating EM (Figure 
A

Primary tumor samples
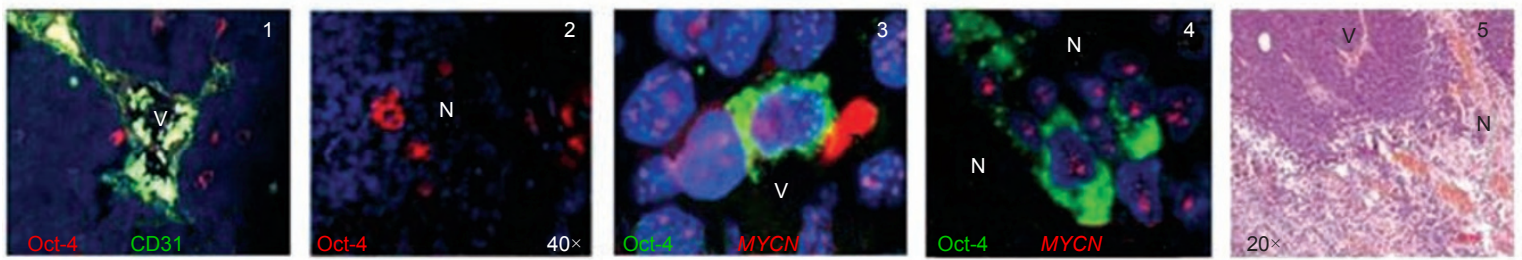

B

Bone marrow samples
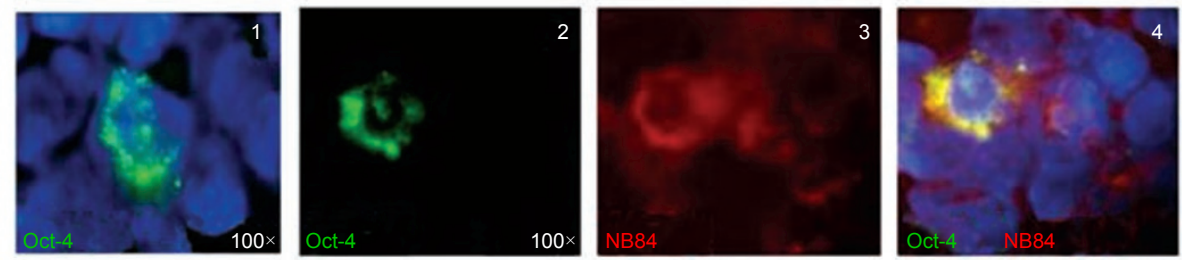

C

NB cell lines

HTLA-230

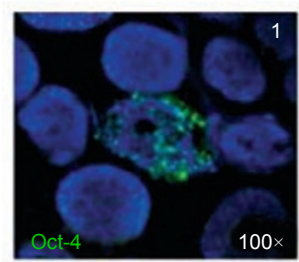

ACN

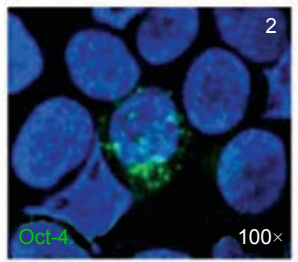

LAN5

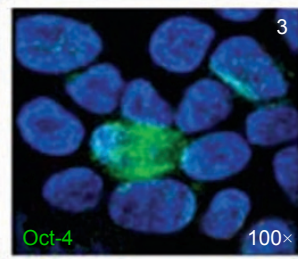

SHSY-5Y

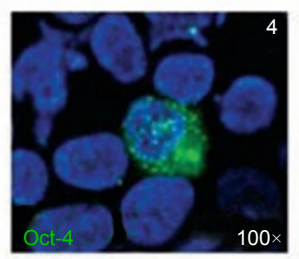

GI-LI-N

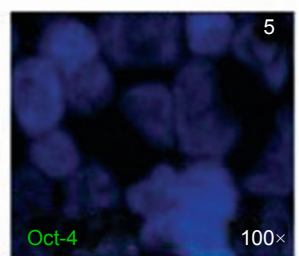

Orthotopic mouse model of human NB
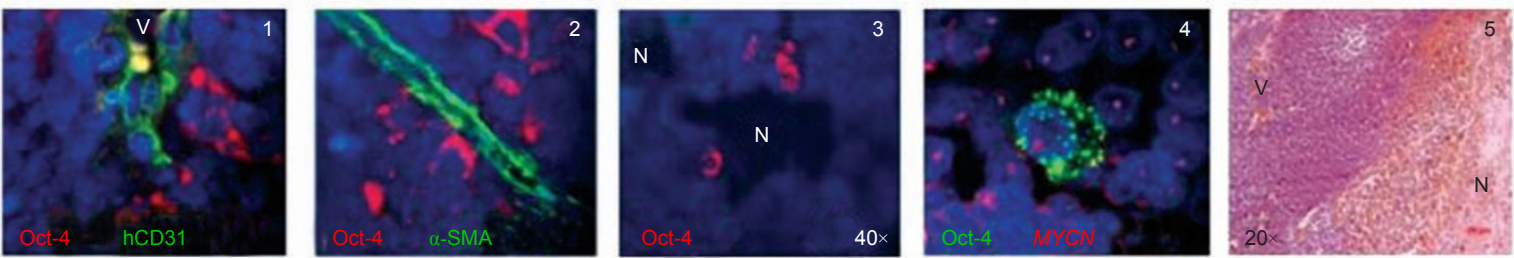

Figure 1 Identification of Oct- $4^{+}$cells in primary NB samples, in metastatic bone marrow samples, in human NB cell lines and in human orthotopic NB tumors formed in immunodeficient mice. (A) (1) Oct-4 ${ }^{+}$cells (red) in primary NB tumor detected by immunofluorescence in perivascular niches ( $\mathrm{V}=$ vessel); (2) Oct- $4^{+}$cells (red) in primary NB tumor located in the perinecrotic area ( $\mathrm{N}=$ necrosis); (3) Oct- $4^{+}$cells (green) in perivascular and (4) perinecrotic areas, respectively, carrying $M Y C N$ amplification as double minutes (red signals), as assessed by FISH. (5) Representative image showing the morphological appearance of primary NB tumor, hematoxylin/eosin staining. (B) (1-2) Oct- $4^{+}$cells (green) in two metastatic bone marrow aspirates; (3) $\mathrm{NB}^{+} 4^{+} \mathrm{NB}$ cells labeled in red; (4) figure showed superimposed composites of Oct-4 and NB84 imaging from the same fields of vision, indicating the tumor origin of Oct- $4^{+}$cells. (C) Oct- $4^{+}$cells (green) in NB cell lines (1) HTLA-230, (2) ACN, (3) LAN5, (4) SHSY-5Y, (5) GI-LI-N is negative. (D) (1) Staining for Oct-4 and hCD31 shows perivascular Oct-4 ${ }^{+}$NB cells (red) close to the hCD $31^{+}$endothelial microvessel (green) in an orthotopic mouse model of human NB. Perivascular Oct- $4^{+}$NB cells accounted for $16.8 \% \pm 2 \%$ of the total cellularity (mean \pm SD from 30 different orthotopic tumors). (2) Staining for Oct-4 and $\alpha$-SMA shows Oct- $4^{+}$cells (red) adherent to $\alpha$-SMA ${ }^{+}$pericytes (green); (3) Oct- $4^{+}$cells next to a perinecrotic (N) area. These cells accounted for $4 \% \pm 2 \%$ of the total cellularity; (4) Anti-Oct- 4 mAb staining combined with MYCN FISH shows that all Oct $-4^{+}$cells (green) harbor MYCN amplification (red). Nuclei are stained with DAPI (blue). (5) Representative image showing the morphological appearance of the orthotopic tumor developed in mouse, hematoxylin/eosin staining. Original magnification $20 \times$ in A5 and D5; 40× in A1, A2 and D3; 100× in all the other panels. 
1D, 2). Notably in this respect, FISH experiments with human $M Y C N$-specific and mouse Cot-1 DNA probes showed that pericytes were always of murine origin (data not shown), similarly to that previously reported in primary NB and in the HTLA-230 pseudometastatic model [8]. As in primary NB, the granular cytoplasmic pattern of Oct-4 staining in orthotopic HTLA-230 tumors prevailed over the nuclear punctate pattern (Figure 1A-1D) [30].

In order to investigate the immunophenotypic profile of perivascular Oct $-4^{+} \mathrm{NB}$ cells from orthotopic tumors, these cells were tested by immunofluorescence for the expression of panels of stem cell-related, neural progenitor-related and NB-related markers. Figure 2A summarizes the differential expression of all the markers investigated in Oct $-4^{+}$vs Oct- $4^{-} \mathrm{NB}$ cells from 10 different orthotopic tumors.

Most Oct $-4^{+}$cells expressed surface TNC, a marker of neural stem/progenitor cells [28] (Figure 2B, 1-3), and HIF-2 $\alpha$ (Figure 2B, 5-7), that controls Oct-4 expression in embryonic stem cells [40] (Figure 2A), but not HIF$1 \alpha$ [35]. HIF- $2 \alpha$, but not TNC, was expressed also by approximately $65 \%$ Oct- $4^{-}$tumor cells (Figure 2B, 5-7 and Figure 2A). Most Oct- $4^{+}$cells co-expressed SOX-2 (Figure 2B, 9-11), another key transcription factor for stemness maintenance $[13,14]$, which was detected also in a small minority of Oct- $4^{-}$NB cells (Figure 2A).

Most Oct $-4^{+}$cells expressed the catalytic subunit of human telomerase (hTERT) [43] (Supplementary information, Figure S1, 1-3) and the cancer stem cell-related markers CD133 [15] (Supplementary information, Figure S1, 5-7), CD24 [44] (Figure 2B, 13-15), CD271 (nerve growth factor receptor p75) [45], as well as $\beta$ III tubulin [46], c-kit and nestin [47, 48] (Figure 2A). hTERT, CD133, CD24, nestin and CD271 were expressed in different proportions also by Oct- 4 tumor cells $(81 \% \pm$ $4 \%, 85 \% \pm 2 \%, 71 \% \pm 4 \%, 33 \% \pm 2 \%$ and $66 \% \pm 5 \%$, respectively, Figure $2 \mathrm{~A}$ ). $\beta$ III tubulin and c-kit were expressed by most Oct- $4^{-}$NB cells (Figure $2 \mathrm{~A}$ ).

Most Oct $-4^{+}$and Oct- $4^{-}$cells expressed VEGF-R2 (Supplementary information, Figure S1, 13-15) [8], and the neuroblastic markers GD2 (Supplementary information, Figure S1, 9-11), CD56 (Supplementary information, Figure S1, 17-19) [8, 49, 50] and NB84 (Figure 2A). All isotypic controls used for immunofluorescence tested negative (Figure 2B, 4, 8, 12, 16; Supplementary information, Figure S1, 4, 8, 12, 16, 20).

In summary, TNC was the only surface marker that was able to discriminate Oct- $4^{+}$and Oct- $4^{-}$cells in orthotopic NB tumors (Figure 2A). Notably in this respect, the few perinecrotic Oct- $4^{+}$cells did not express TNC.
Identification of perivascular Oct- $4^{+} / \mathrm{TNC}^{+}$cells in primary tumors and $N B$ cell lines

We next asked whether perivascular Oct $-4^{+}$cell coexpressing TNCs that had been detected in HTLA230 orthotopic tumors were present also in primary NB

Table 1 Demographic characteristics of NB patients and percentage of Oct- $4^{+}$cells in primary tumor samples and in bone marrow (BM) aspirate samples

\begin{tabular}{|c|c|c|c|c|c|}
\hline \multicolumn{2}{|c|}{$\begin{array}{l}\text { Patient primary } \\
\text { tumor sample }\end{array}$} & \multicolumn{2}{|c|}{ Age (months) } & Stage & $\%$ Oct- $4^{+}$cells \\
\hline 1 & & $<12$ & & 1 & 12 \\
\hline 2 & & $<12$ & & 1 & 4 \\
\hline 3 & & $<12$ & & 1 & 14 \\
\hline 4 & & $<12$ & & 1 & 15 \\
\hline 5 & & $<12$ & & 1 & 30 \\
\hline 6 & & $>12$ & & 1 & 4 \\
\hline 7 & & $>12$ & & $2 \mathrm{~A}$ & 0 \\
\hline 8 & & $<12$ & & $2 \mathrm{~A}$ & 10 \\
\hline 9 & & $>12$ & & $2 \mathrm{~B}$ & 10 \\
\hline 10 & & $>12$ & & $2 \mathrm{~B}$ & 4 \\
\hline 11 & & $>12$ & & $2 \mathrm{~B}$ & 2 \\
\hline 12 & & $<12$ & & $4 \mathrm{~s}$ & 10 \\
\hline 13 & & $<12$ & & $4 \mathrm{~s}$ & 0 \\
\hline 14 & & $<12$ & & $4 \mathrm{~s}$ & 4 \\
\hline 15 & & $>12$ & & 4 & 2 \\
\hline 16 & & $>12$ & & 4 & 4 \\
\hline 17 & & $>12$ & & 4 & 15 \\
\hline 18 & & $>12$ & & 4 & 2 \\
\hline 19 & & $>12$ & & 4 & 10 \\
\hline 20 & & $>12$ & & 4 & 30 \\
\hline 21 & & $>12$ & & 4 & 15 \\
\hline 22 & & $>12$ & & 4 & 3 \\
\hline 23 & & $>12$ & & 4 & 15 \\
\hline $\begin{array}{l}\text { Patient BM } \\
\text { sample }\end{array}$ & $\begin{array}{c}\text { Age } \\
\text { (months) }\end{array}$ & & Stage & $\% \mathrm{NB}^{2} 4^{+}$cells & $\begin{array}{c}\% \text { Oct }-4^{+} / \\
\mathrm{NB}^{+} 4^{+} \text {cells }\end{array}$ \\
\hline 1 & $>12$ & & 4 & 30 & 0.2 \\
\hline 2 & $>12$ & & 4 & 20 & 0.4 \\
\hline 3 & $>12$ & & 4 & 70 & 0.15 \\
\hline 4 & $>12$ & & 4 & 80 & 0.15 \\
\hline 5 & $>12$ & & 4 & 30 & 0.4 \\
\hline 6 & $>12$ & & 4 & 80 & 1.5 \\
\hline 7 & $>12$ & & 4 & 60 & 0.2 \\
\hline 8 & $>12$ & & 4 & 80 & 0.7 \\
\hline 9 & $>12$ & & 4 & 10 & 0.8 \\
\hline 10 & $>12$ & & 4 & 50 & 0.4 \\
\hline
\end{tabular}


A

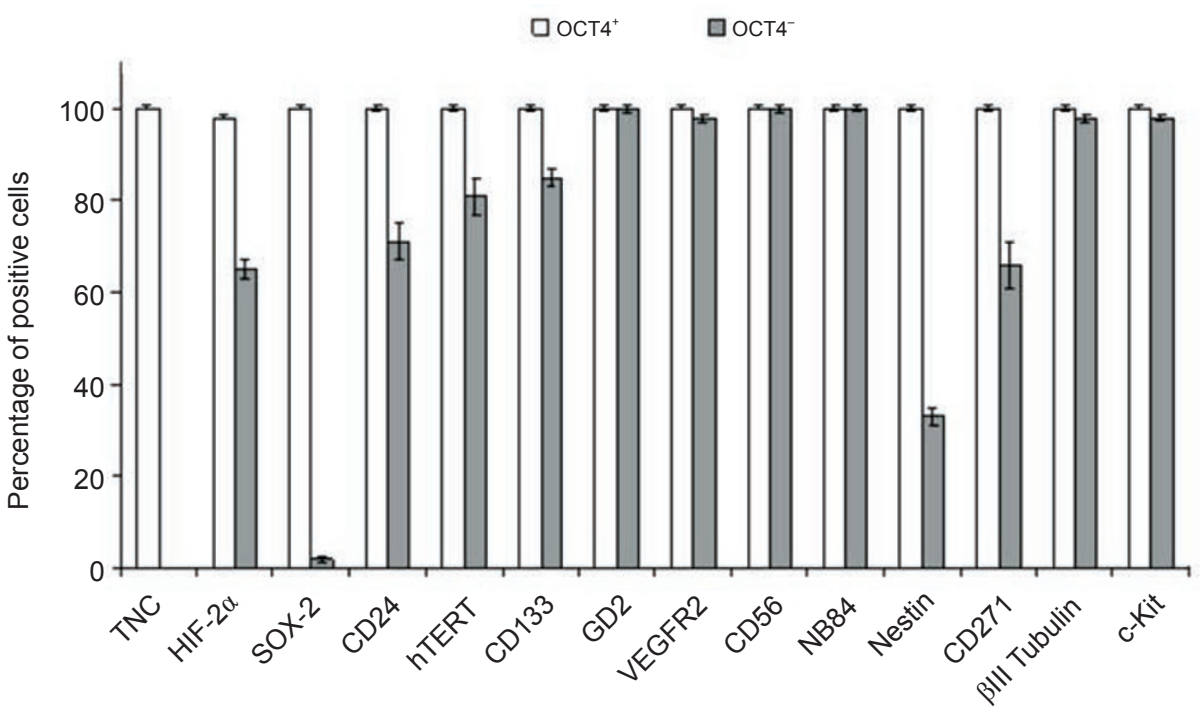

B
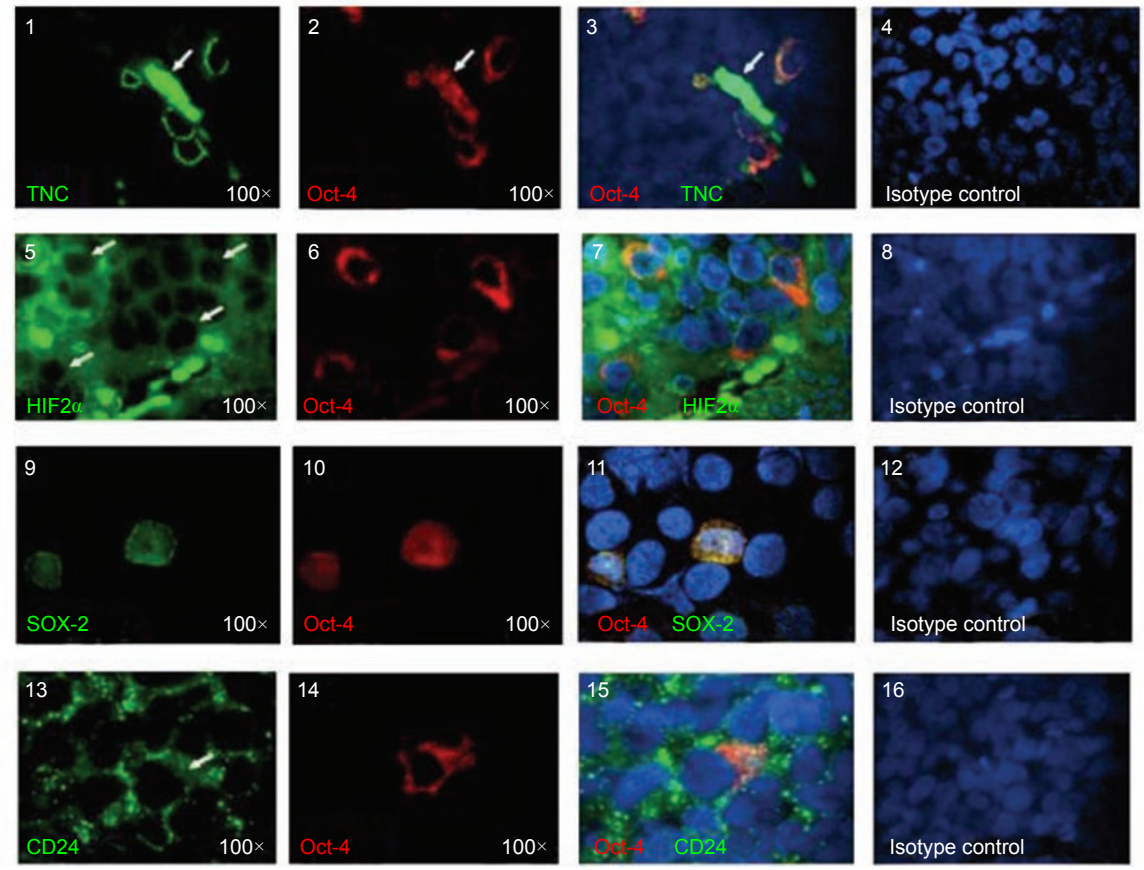

Figure 2 Immunophenotype of perivascular Oct- $4^{+}$NB cells from orthotopic NB tumors formed by HTLA-230 NB cells in immunodeficient mice. (A) Immunofluorescence analyses show the differential expression of TNC, HIF-2 $\alpha$, SOX-2, CD24, hTERT, CD133, GD2, VEGFR2, CD56, NB84, Nestin, CD271, $\beta$ III Tubulin, c-Kit in Oct- $4^{+}$and in Oct-4 ${ }^{-}$NB cells. Columns represent mean values obtained from the count of 20 fields/slide in 10 different orthotopic NB tumors formed by HTLA230 cells; bars represent SD. (B) (1-3) Representative micrographs showing co-expression of Oct-4 (red) and TNC (green) within the orthotopic tumors. (1) Single staining for TNC (green) and (2) Oct-4 (red), respectively. (3) Double immunofluorescence staining (yellow, merge) for Oct-4 (red) and TNC (green). The arrows indicated green and red auto-fluorescence of erythrocytes present in the lumen of microvessel. (5-7) Co-expression of Oct-4 (red) and HIF-2 $\alpha$ (green) within the orthotopic tumors. (5) Single staining for HIF-2 $\alpha$ (green) and (6) Oct-4 (red), respectively. (7) Double immunofluorescence staining (yellow, merge) for Oct-4 (red) and HIF-2 $\alpha$ (green). (9-11) Co-expression of Oct-4 (red) and SOX-2 (green) within the orthotopic tumors. (9) Single staining for SOX-2 (green) and (10) Oct-4 (red), respectively. (11) Double immunofluorescence staining (yellow, merge) for Oct-4 (red) and SOX-2 (green). (13-15) Co-expression of Oct-4 (red) and CD24 (green) within the orthotopic tumors. (13) Single staining for CD24 (green) and (14) Oct-4 (red), respectively. (15) Double immunofluorescence staining (yellow, merge) for Oct-4 (red) and CD24 (green). $(4,8,12,16)$ Isotypic controls. Nuclei are stained with DAPI (blue). All photomicrographs are original magnification $100 \times$. 
samples. Therefore, we stained by double immunofluorescence tissue sections from 10 primary tumors (out of the 23 previously tested, see Table 1) with anti-Oct-4 and anti-TNC mAbs. Perivascular but not perinecrotic Oct- $4^{+}$ cells were found to express surface TNC (range from $3 \%$ to $29 \%$ ) (Figure $3 \mathrm{~A}$ ), similarly to that observed in the HTLA-230 orthotopic model (see Figure 2B, 1-3). In contrast, TNC was never expressed by Oct- $4^{-}$cells from primary tumors.

Oct- $4^{+}$cells from in vitro cultured HTLA-230, SHSY$5 \mathrm{Y}, \mathrm{ACN}$, and LAN-5 NB cell lines also co-expressed surface TNC that was undetectable on Oct- $4^{-}$cells from these cell lines as well as on the Oct- $4^{-}$GI-LI-N cells (Figure 3A). One representative experiment showing

A

\%Oct-4+TNC+cells

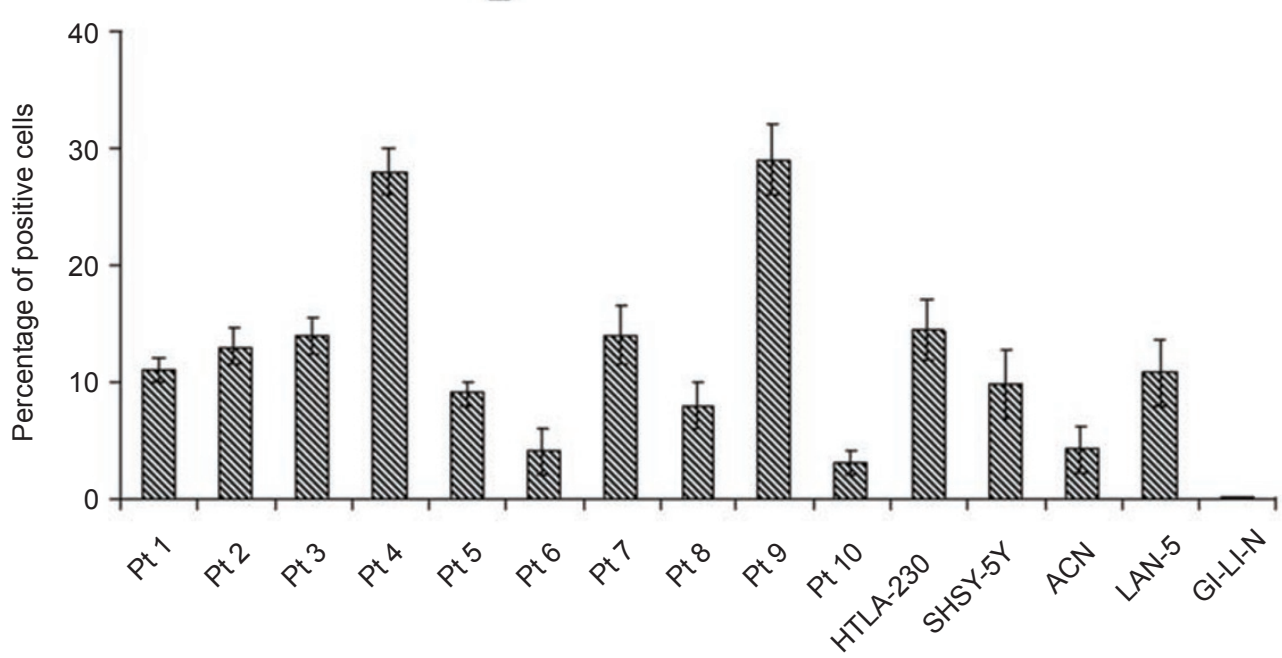

B
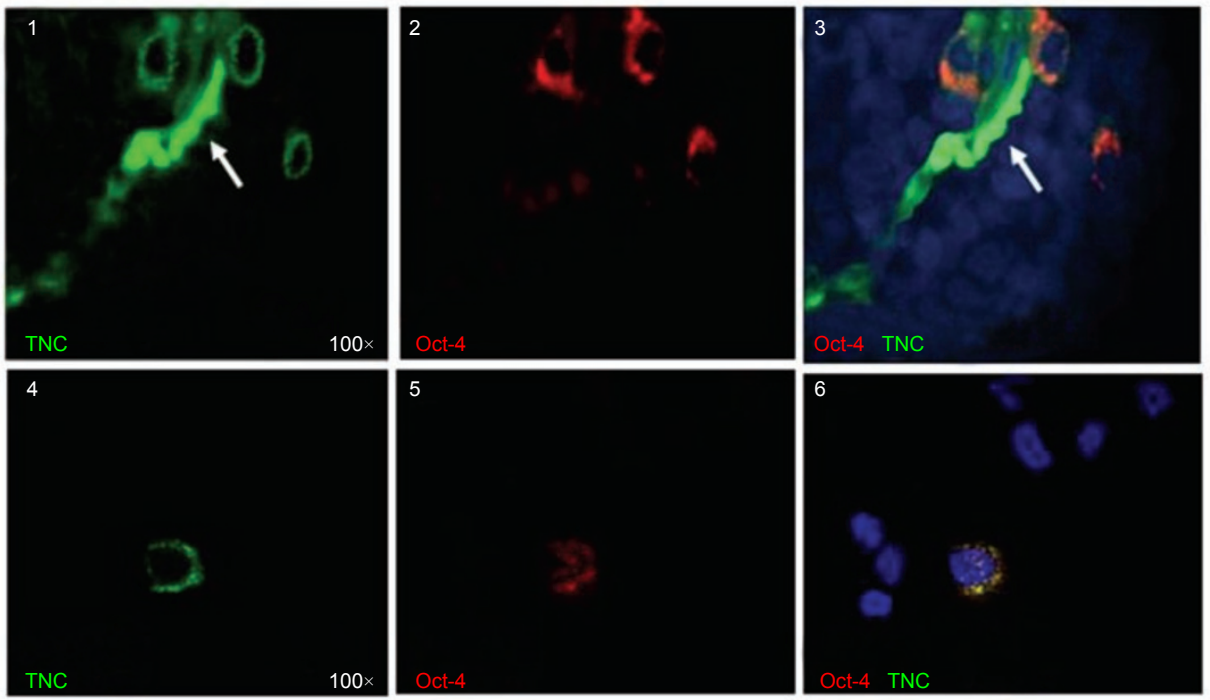

Figure 3 Oct- $4^{+}$cells from primary NB tumors and NB cell lines co-express TNC. (A) Double immunofluorescence analysis shows co-expression of Oct- 4 and TNC in 10 primary NB tumors and in 5 different NB cell lines. Columns represent the mean percent values from 20 fields/slide; bars represent SD. (B) Co-expression of Oct-4 (red) and TNC (green) within the primary tumors. (1) Single staining for TNC (green) and (2) Oct-4 (red), respectively. (3) Double immunofluorescence staining (yellow, merge). The arrow indicated auto-fluorescence of erythrocytes present in the lumen of microvessel. (4-6) Co-expression of Oct-4 (red) and TNC (green) in in vitro cultured HTLA-230 NB cells. (4) Single staining for TNC (green) and (5) Oct-4 (red), respectively; (6) Double staining (yellow, merge) for Oct-4 (red) and TNC (green). Nuclei are stained with DAPI (blue). All photomicrographs are original magnification $100 \times$. 
co-expression of Oct- 4 and TNC in cytospins from the HTLA-230 cell line is shown in Figure 3B, 4-6.

Expression of TNC mRNA in human HTLA-230 cell line

In order to exclude the possibility that detection of surface TNC on NB cells was due to release of soluble $\mathrm{TNC}$ from the tumor extracellular matrix and subsequent binding to receptors expressed on malignant cells, we next performed real-time PCR experiments with specific primers detecting all TNC isoforms [28] using mRNA from the $\mathrm{TNC}^{+}$HTLA-230 and TNC ${ }^{-}$GI-LI-N NB cell lines. As shown in Supplementary information, Figure 2S, TNC mRNA was detected in HTLA-230 but not GILI-N cells, indicating that the former cells produced TNC endogenously.

Orthotopic NB tumors formed by $T N C^{+}$but not $T N C^{-}$ HTLA-230 cells contain EMs lined by TECs

Next, we asked whether $\mathrm{TNC}^{+} / \mathrm{Oct}-4^{+} \mathrm{NB}$ cells could serve as TEC progenitors and therefore contribute to tumor vasculogenesis. Tumor-derived TNC promotes or enhances the process of neovascularization in different tumor models [23-28, 51].

In preliminary experiments, we investigated whether orthotopic tumors formed by HTLA-230 cells in nude mice contained EM lined by TEC. Indeed, tumors harvested after 3 weeks from malignant cell inoculation contained approximately a half of mouse EM and the other half of human EM (data not shown), as previously demonstrated in the HTLA-230 pseudo-metastatic model [8].

We next isolated $\mathrm{TNC}^{+}$and $\mathrm{TNC}^{-} \mathrm{HTLA}^{-230}$ cells with high degree of purity by a two-round immunomagnetic procedure. Either cell fraction was inoculated orthotopically in two groups of six nude mice each. Tumors formed by $\mathrm{TNC}^{+}$and $\mathrm{TNC}^{-} \mathrm{HTLA}-230$ cells were harvested after 3 weeks. The average volume of tumors formed by $\mathrm{TNC}^{+}$cells was larger than that formed by $\mathrm{TNC}^{-}$cells $(P=0.039)$ (Figure $\left.4 \mathrm{D}\right)$. Tumors formed by both $\mathrm{TNC}^{+}$and $\mathrm{TNC}^{-}$cells were subjected to EM count by immunofluorescence with hCD31 and mCD34 mAbs that proved to be rigorously species-specific in a previous study from our group [8]. EM lined by hCD31 $1^{+}$TEC represented approximately a half of the EM present in tumors formed by $\mathrm{TNC}^{+} \mathrm{HTLA}-230$ cells $(49 \% \pm 1.35 \%)$, the remaining $\mathrm{EM}$ being lined by $\mathrm{mCD} 34^{+} \mathrm{EC}(51 \% \pm$ $1.35 \%$ ) (Figure 4A and 4B). In contrast, all EM present in tumors formed by $\mathrm{TNC}^{-}$HTLA-230 cells were lined by $\mathrm{mCD} 34^{+} \mathrm{EC}$ (Figure 4A and $4 \mathrm{C}$ ). Finally, orthotopic tumors formed by the $\mathrm{TNC}^{-} / \mathrm{Oct}^{-} 4^{-}$GI-LI-N NB cell line contained mouse EM only (data not shown).

In the orthotopic tumors formed by $\mathrm{TNC}^{+} \mathrm{HTLA}-230$ cells, mean overall EM density was 29.2 microvessels per $40 \times$ field visually (range 12.8-94.3). In the orthotopic tumors formed by $\mathrm{TNC}^{-}$HTLA-230 cells mean overall EM density was 7.4 microvessels per $40 \times$ field visually (range 0.0-24). Therefore, in tumors formed by $\mathrm{TNC}^{+}$ HTLA-230 cells microvessel density was significantly higher than in those formed by $\mathrm{TNC}^{-}$HTLA-230 cells $(P$ $=0.022$ ).

These experiments demonstrate unambiguously that $\mathrm{TNC}^{+} \mathrm{NB}$ cells contained TEC progenitors.

\section{Kinetics of human and mouse EM formation in orthotopic} tumors formed by $\mathrm{TNC}^{+}$cells in immunodeficient mice

In order to investigate the kinetics of development of tumor microvessels lined by human or mouse EC, nude mice were inoculated orthotopically with the $\mathrm{TNC}^{+}$ HTLA-230 cells [42] and groups of six mice each were sacrificed at various times. ECs lining EM were detected by staining with anti-mCD34 and anti-hCD31 mAbs [8]. After an initial predominance of mouse over human EM, the two types of EM reached an equilibrium. Both the increment in the proportion of human EM and the decrease of mouse EM on day 35 compared to day 7 were statistically significant $(P=0.038$ for both comparisons) (Figure $5 \mathrm{~A})$. Human EM contained intra-luminal red blood cells (Figure 5B, 3), indicative of their contribution to tumor vascularization. Individual EMs lined by juxtaposed mouse ECs and human TECs were never detected.

We next investigated expression of additional EC-related markers and of NB-related markers in human TECs from orthotopic tumors harvested 3 weeks after inoculation of $\mathrm{TNC}^{+}$HTLA-230 cells (Figure 6A). Most TECs were found to express the EC-related markers PSMA [52] (Figure 6B, 1) and hvWF (Figure 6B, 2). These cells were tumor-derived since they carried $M Y C N$ amplification as homogeneously staining regions (Figure 6B, 1 and 2). Most human TECs expressed hCD105, a marker of EC activation [53] (Figure 6B, 3), HLA-class I (Figure $6 \mathrm{~B}, 4)$ but not HLA-class II (data not shown) antigens, as well as HLA-G, a non-polymorphic HLA-class Ib molecule expressed by embryonic cytotrophoblast cells and endowed with potent immunosuppressive activities [54] (Figure 6B, 5). At variance with TEC, bulk tumor cells did not express PSMA, vWF, CD105, HLA-class I or HLA-G (Figure 6A). Most TECs were found to express the NB-associated markers GD2 [49] NB84 [41], and CD56 [50] (Figure 6B, 6-8), which were shared by most tumor cells (Figure 6A).

Plasticity of TNC $C^{+}$cells isolated from the HTLA-230 cell line

In subsequent experiments, we investigated the plas- 
A

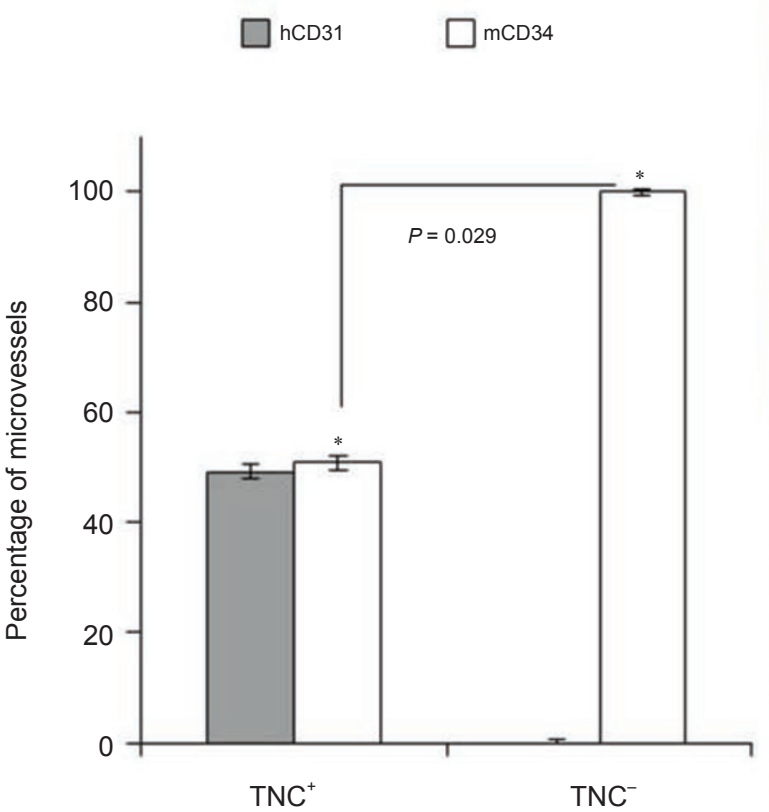

D

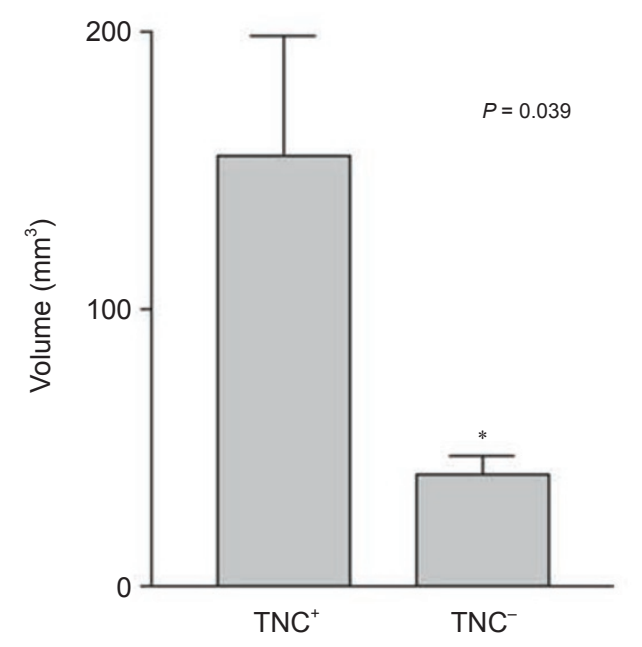

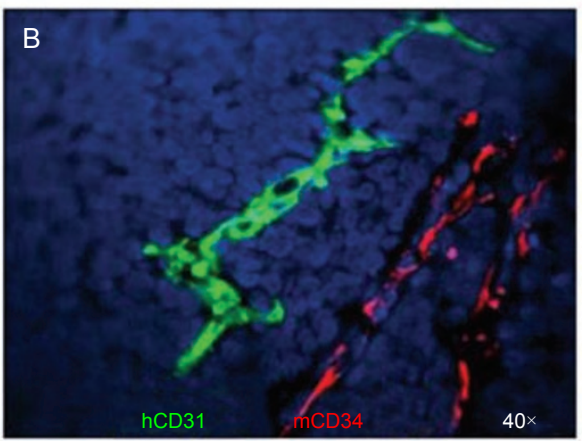
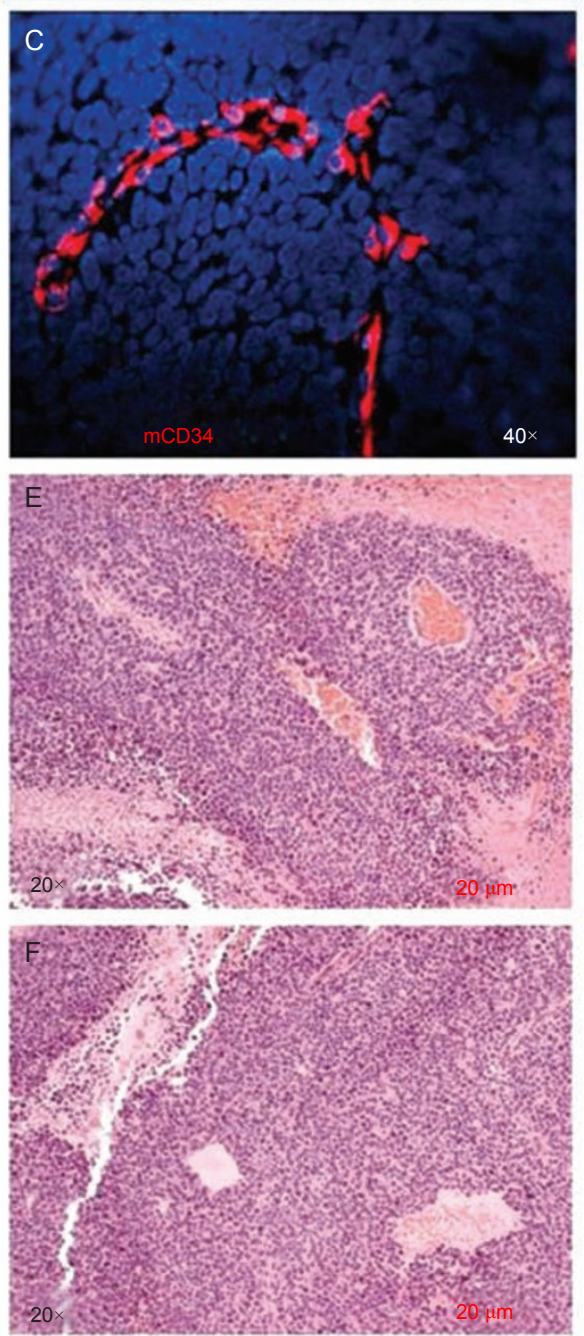

Figure 4 Orthotopic NB tumors formed by $\mathrm{TNC}^{+}$, but not $\mathrm{TNC}^{-}$cells, from the HTLA-230 cell line contain endothelial microvessels lined by tumor-derived endothelial cells. $\mathrm{TNC}^{+}$cells were isolated from HTLA-230 NB cells by magnetic cell sorting using anti-TNC mAb. TNC-enriched and TNC-depleted cells were injected orthotopically in nude mice. (A) Human (grey columns) and murine (white columns) microvessels in orthotopic tumors formed by $\mathrm{TNC}^{+}$and $\mathrm{TNC}^{-}$cells in immunodeficient mice. Columns represent mean percent values from 12 different tumors; bars represent SD $(P=0.029$; Mann-Whitney test). (B) Double immunofluorescence staining of ortothopic tumors formed by TNC ${ }^{+}$cells with hCD31 (green) and mCD34 (red) mAbs. (C) Double immunofluorescence staining of ortothopic tumors formed by $\mathrm{TNC}^{-}$cells with hCD31 (green) and mCD34 (red) mAbs. Nuclei are stained with DAPI (blue). (B, C) Original magnification 40×. (D) Quantification of the volume of tumors formed by $\mathrm{TNC}^{+}$and $\mathrm{TNC}^{-}$cells demonstrated that $\mathrm{TNC}^{+}$cells formed significantly larger tumors than $\mathrm{TNC}^{-}$cells $(* P=0.039)$. (E) Hematoxylin/eosin staining of orthotopic tumor formed by $\mathrm{TNC}^{+}$cells. (F) Hematoxylin/eosin staining of orthotopic tumor formed by $\mathrm{TNC}^{-}$cells. (E, F) Original magnification $20 \times$. 
A

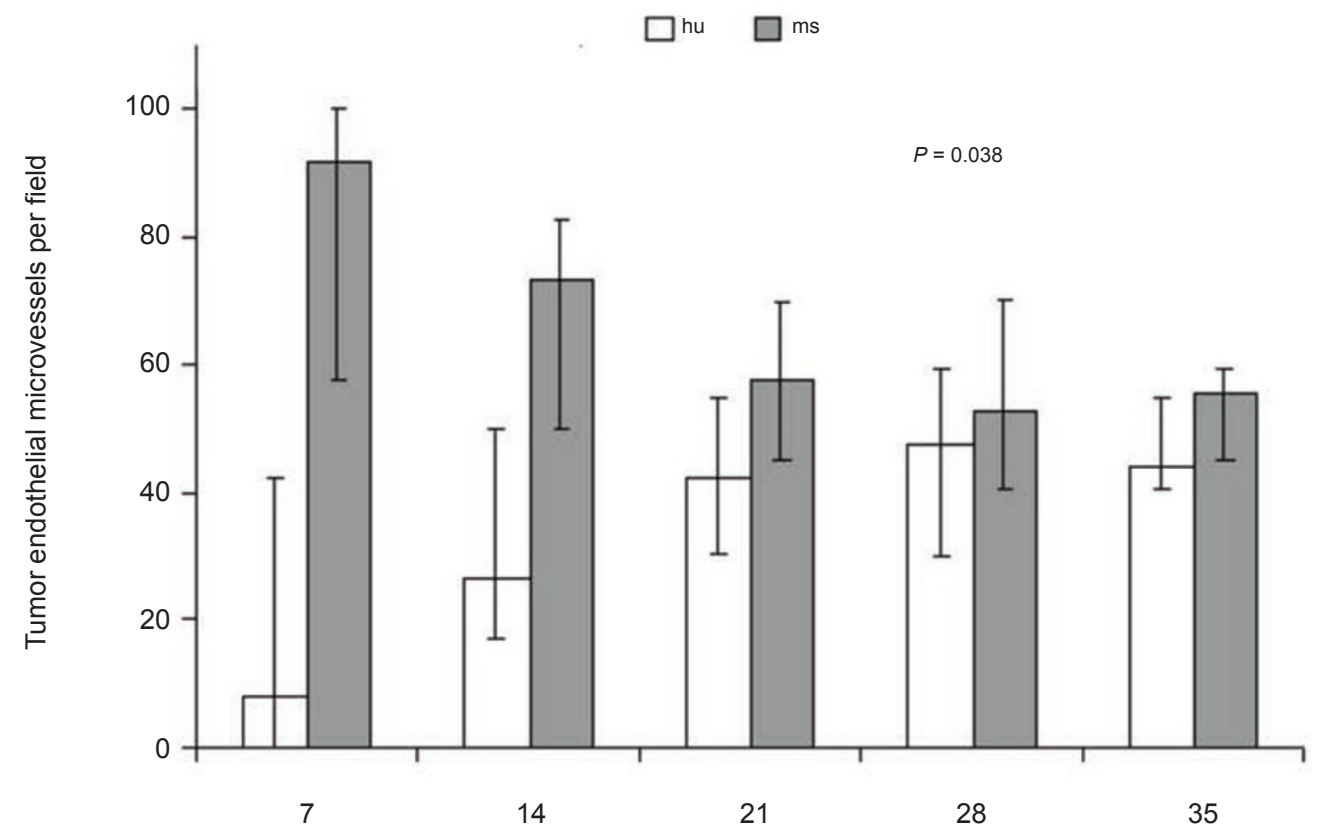

Days after orthotopic inoculation of $\mathrm{TNC}^{+}$cells

B
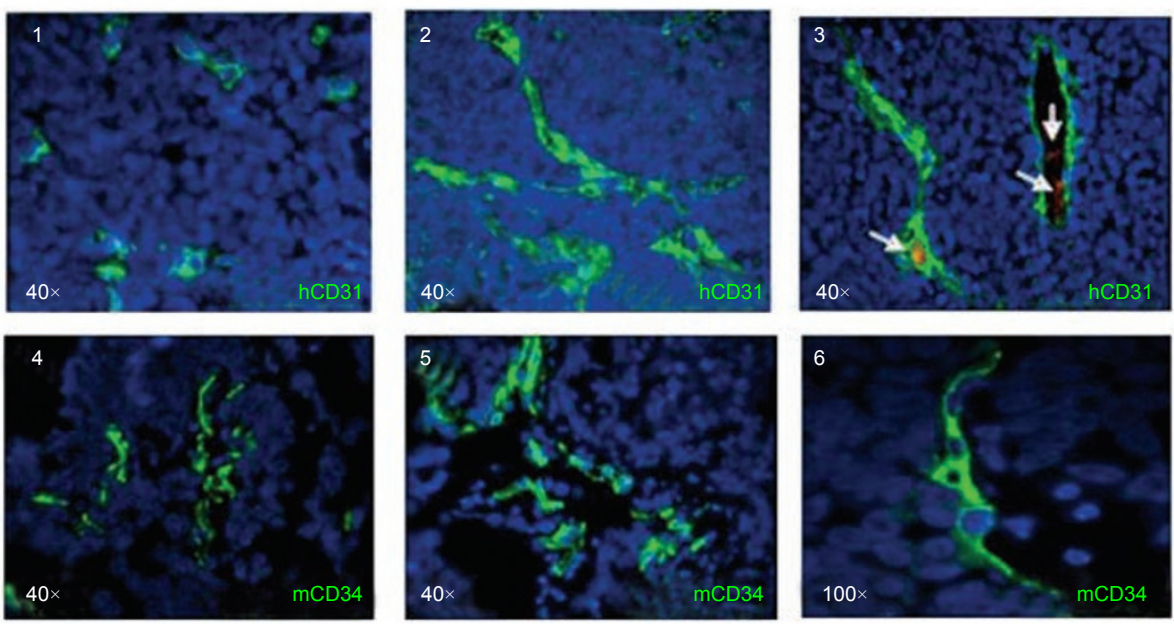

Figure 5 Kinetics of human and mouse endothelial microvessel formation in orthotopic tumors formed by $\mathrm{TNC}^{+}$cells in immunodeficient mice. (A) Kinetics of hCD31 ${ }^{+}$(white columns) and $\mathrm{mCD} 34^{+}$(grey columns) tumor endothelial microvessels per field (expressed as median percentages from 20 different tumors) from 7 to 35 days after orthotopic inoculation of TNC ${ }^{+}$cells isolated from HTLA-230 cell line. (B) (1) On day 7, CD31+ human endothelial cells appear as small clusters, as assessed by immunofluorescence. (2-3) From day 14 human endothelial microvessels display mature morphology. Erythrocytes are visible in the lumen of most human microvessels (arrows). (4) On day 7, CD34 $4^{+}$mouse endothelial cells lined nascent endothelial microvessels. (5-6) From day 14 mouse endothelial microvessels display mature morphology. Nuclei are stained with DAPI (blue). Original magnification $100 \times$ in B6; $40 \times$ in all the other panels.

ticity of $\mathrm{TNC}^{+}$cells from the HTLA-230 cell line in three different in vitro models, i.e., the ability to form neurospheres or tubes and the potential to differentiate into endothelial-like cells.
When cultured in serum-free medium promoting neurosphere formation, $\mathrm{TNC}^{+}$cells grew in suspension and generated neurospheres (Figure $7 \mathrm{~A}, 1$ ), whereas $\mathrm{TNC}^{-}$ cells did not (Figure 7A, 2). Notably, the latter cells 
A

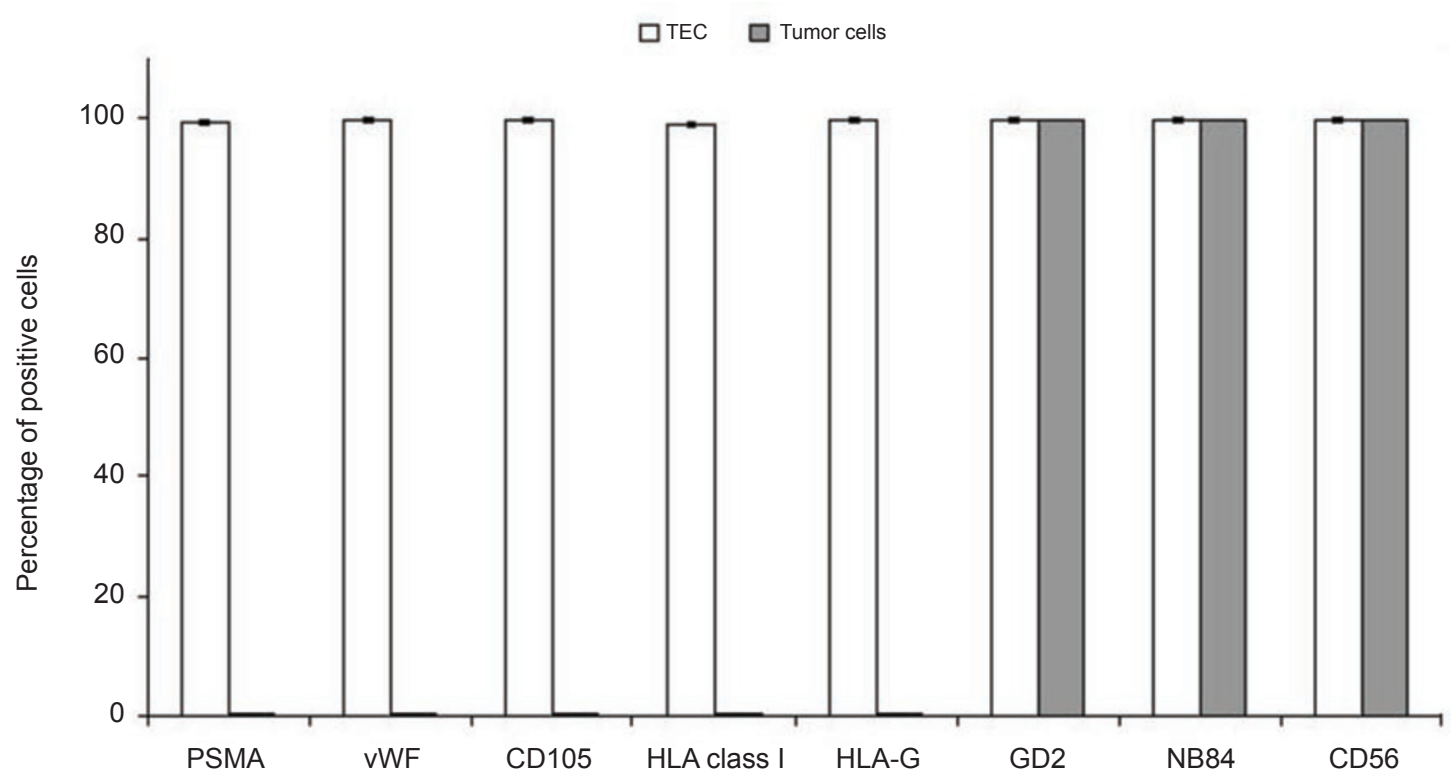

B
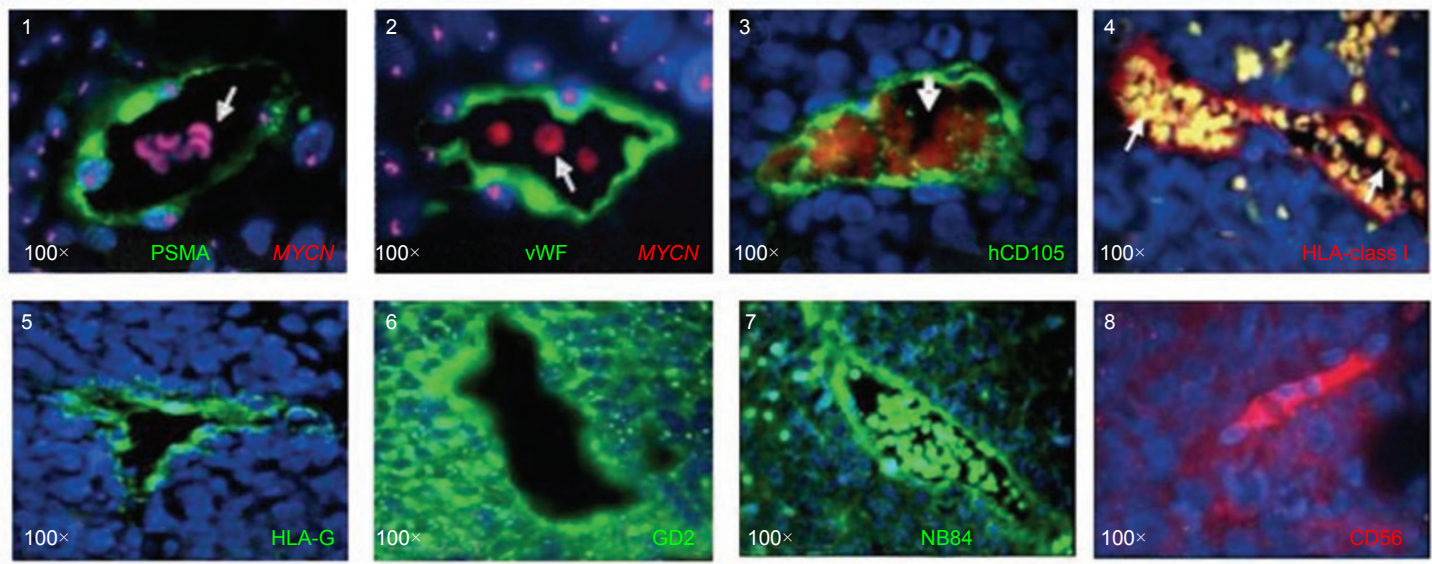

Figure 6 Immunophenotypic characterization of human endothelial microvessels in orthotopic tumors formed by TNC ${ }^{+}$NB cells in immunodeficient mice. (A) Immunofluorescence analyses show the expression of PSMA, von Willebrand factor (vWF), CD105, HLA-class I, HLA-G, GD2, NB84 and CD56 in TEC and in tumor cells. Columns represent mean values obtained from the count of 20 fields/slide in 10 different orthotopic NB tumors formed by $\mathrm{TNC}^{+}$cells; bars represent SD. (B) (1-2) Immunophenotype of human endothelial microvessels as assessed by immunofluorescence combined with MYCN FISH. (1) Tissue sections were stained with anti-PSMA (green), (2) anti-vWF (green), (3) anti-hCD105 (green), (4) anti-HLA-class I, (5) anti-HLAG, (6) anti-GD2, (7) anti-NB84, and (8) anti-CD56. Nuclei are stained with DAPI (blue). Original magnification 40× in B5 and $100 \times$ in other images.

showed morphological evidence of differentiation represented by neurite formation (Figure 7A, 2) as did the parental cell line (data not shown).

To evaluate whether the ability to form neurospheres was maintained, primary neurospheres, enzymatically digested after 7-10 days and re-plated as single-cell suspension, generated second passage spheres. This feature was retained for 10 passages. Neurospheres expressed $\beta I I I$ tubulin, nestin, HIF- $2 \alpha$, CD24, Oct- 4 , and Notch-2
[55] (Figure 7B, 1-4), but not CD34, PSMA, CD31 or VE-cadherin.

We next used a $3 \mathrm{D}$ in vitro system with high-density Matrigel to investigate the ability of $\mathrm{TNC}^{+}$and $\mathrm{TNC}^{-}$ HTLA-230 cells to form tubes resembling vascular structures. Normal ECs isolated from human umbilical vein (HUVECs) were tested as control.

In four different experiments, both $\mathrm{TNC}^{+}$and $\mathrm{TNC}^{-}$ cells formed a network of tubes (Figure 7A, 3 and 4), 
A
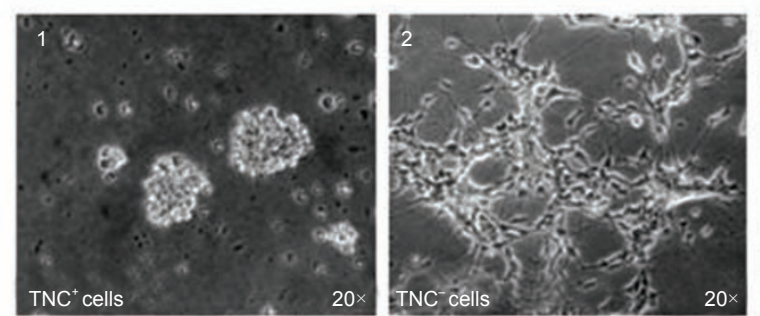

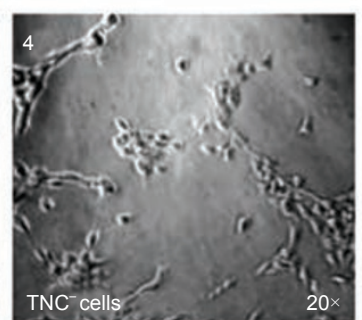

INC cells
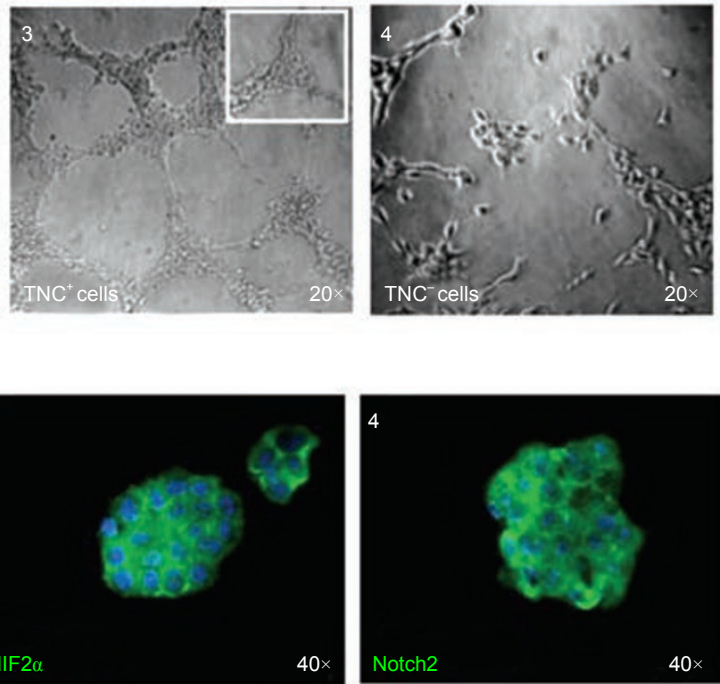

B
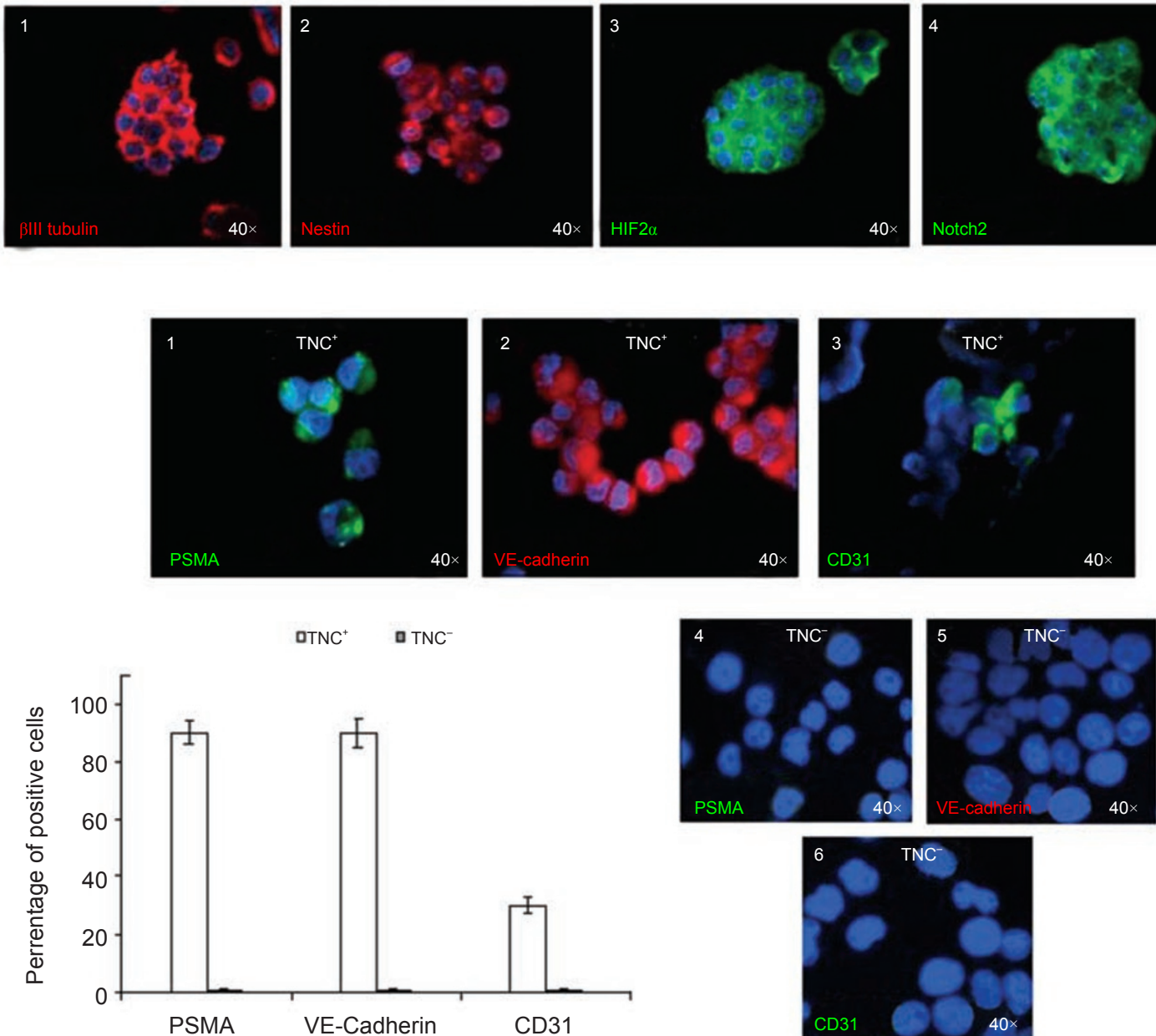

Figure 7 Plasticity of $\mathrm{TNC}^{+}$cells isolated from the HTLA-230 cell line. (A) (1) $\mathrm{TNC}^{+}$cells enriched from the HTLA-230 NB cell line and cultured in serum-free medium supplemented with bFGF and EGF form neurospheres in vitro. (2) TNC $^{-}$cells grow as an adherent layer in serum-free medium supplemented with bFGF and EGF as parental cell line. (3) Representative micrograph of the complete network of tubes formed by TNC ${ }^{+}$cells $\left(1-3 \times 10^{4}\right.$ cells/well) plated on growth factor-reduced Matrigel after stimulation with VEGF $(5-15 \mathrm{ng} / \mathrm{ml})$ and bFGF $(20-50 \mathrm{ng} / \mathrm{ml})$ after $6 \mathrm{~h}$. Tubes of the TNC ${ }^{+}$cells persisted for up to 5 days. The inset shows an enlargement of a detailed network of tubes. (4) Representative micrograph of the weak network of tubes formed by TNC $^{-}$cells $\left(1-3 \times 10^{4}\right.$ cells/well) plated on Matrigel. Structures of TNC ${ }^{-}$cells rapidly dissolved in a few hours. (B) (1) Neurospheres express $\beta$ III tubulin (red), (2) nestin (red), (3) HIF-2 $\alpha$ (green), (4) Notch 2 (green), as assessed by immunofluorescence with specific mAbs. (C) (1) TNC ${ }^{+}$cells cultured in differentiating medium supplemented with $2 \%$ FCS and VEGF for 10-15 days acquire expression of the endothelial-specific markers PSMA, (2) VE-Cadherin, and (3) CD31. (46) $\mathrm{TNC}^{-}$cells did not express the markers. (4), (5) and (6) show negative staining for PSMA, VE-Cadherin and CD31 of TNC ${ }^{-}$ cells cultured in endothelial differentiation medium. Nuclei are stained with DAPI (blue). Original magnification 40×. Lower left panel, PSMA and VE-Cadherin were upregulated in more than $90 \%$ of the differentiating TNC ${ }^{+}$cells, while CD31 was detected on approximately $30 \%$ of them. Columns (TNC ${ }^{+}$white columns and $\mathrm{TNC}^{-}$grey columns) represent mean values from five replicate experiments; bars represent SD. 
similar to those observed with HUVECs. However, the kinetics of formation of tubes was definitely faster with $\mathrm{TNC}^{+}$than with $\mathrm{TNC}^{-}$cells. Thus, the former cells gave rise to a network of tubes $2 \mathrm{~h}$ after plating and complete tube formation was detected after $6 \mathrm{~h}$. In contrast, $\mathrm{TNC}^{-}$ cells started forming the network of tube structures after $12 \mathrm{~h}$ and reached a plateau after $20 \mathrm{~h}$ in culture. Tubes formed by $\mathrm{TNC}^{+}$cells persisted for up to 5 days, while tubular structures generated by $\mathrm{TNC}^{-}$cells rapidly dissolved in a few hours. Furthermore, the network of tubes formed by $\mathrm{TNC}^{+}$cells was thicker and more branched than that generated by $\mathrm{TNC}^{-}$cells, which displayed a less-organized morphology (Figure 7A, 3 and 4). The number of branches of the tube network formed by $\mathrm{TNC}^{+}$cells was higher than that formed by $\mathrm{TNC}^{-}$cells $\left(\mathrm{TNC}^{+}\right.$cells, $70 \pm 27 \mathrm{vs} \mathrm{TNC}^{-}$cells, $23 \pm 12$ branches per field; $P=0.004$ ).

GI-LI-N NB cells, which did not give rise to TECs in orthotopic tumors, were also tested in the same highdensity Matrigel system mentioned above. GI-LI-N cells formed tubes already after $2 \mathrm{~h}$ that waned after 4-6 h, suggesting that these tubular structures were unstable (data not shown).

Finally, $\mathrm{TNC}^{+}$cells were grown in differentiating EndoGRO-MV-VEGF medium supplemented with VEGF. In this condition, $\mathrm{TNC}^{+}$cells lost $\mathrm{TNC}$ expression after 3 days in culture (data not shown) and acquired expression of the endothelial-specific markers PSMA, VE-cadherin, and CD31 after 10-15-day culture (Figure 7C, 1-3). In three different experiments, PSMA and VE-cadherin were upregulated on higher than $90 \% \mathrm{TNC}^{+}$cells, while CD31 was detected on $30 \%$ of them. PSMA, VE-cadherin and CD31 were undetectable in $\mathrm{TNC}^{-}$cells cultured for 10-15 days in EndoGRO-MV-VEGF medium supplemented with VEGF (Figure 7C, 4-6).

\section{Discussion}

The concept of vascular mimicry, originally referred to the ability of highly aggressive human melanoma cells to form vascular channels in vivo and in vitro [7], has been extended to indicate the differentiation of tumor cells into ECs witnessed by de novo expression of ECspecific genes [7].

Vascular mimicry has been reported in different tumors [7-11]. Although the mechanisms underlying differentiation of human tumor cells into EM are largely unknown, a few studies provide insights into the nature of the malignant cells involved in the phenomenon. Thus, Bussolati et al. [56] have shown that $\mathrm{CD} 105^{+}$tumorinitiating cells from renal carcinoma can differentiate into TECs in vitro and generate human microvessels in immunodeficient mice. The same group has demonstrated that breast cancer stem/progenitor cells are capable of differentiating into TECs [9]. Likewise, Alvero et al. [57] have shown that TECs may originate from a subset of ovarian cancer cells with a highly angiogenic phenotype and the features of cancer stem cells. The connection between neural stem cells and the endothelial compartment seems to be critical in glioblastoma, where cancer stem cells closely interact with the vascular niche and promote angiogenesis [58]. It has been proposed that genetically abnormal TECs display an embryonic/immature phenotype associated with increased angiogenic potential, leading to embryonic-like vasculogenesis in the tumor microenvironment [53].

We have previously demonstrated in a pseudo-metastatic tumor model that both primary NB cells and NB cell lines generate TECs lining the EM coated by hostderived pericytes $[8,10]$.

Previous studies $[20,22]$ have demonstrated that sidepopulation cells of the SK-NB-BE(2) NB cell line and tumor-initiating human NB cells express the embryonic stem cell [12-14] and cancer stem cell marker Oct-4 [1520]. The human Oct- 4 gene can generate at least three transcripts (Oct-4A, Oct-44B and Oct-4B1) and four protein isoforms (OCT4A, OCT4B-190, OCT4B-265 and OCT4B-164) by alternative splicing and alternative translation initiation [31]. The Oct-4A isoform confers pluripotency on ES cells.

In this study, we first investigated Oct-4A expression in primary $\mathrm{NB}$ at different stages and detected variable amounts of Oct $-4^{+}$cells in most of them. Lower proportions of Oct $-4^{+}$cells were found in metastatic BM samples. This latter finding may be explained by the fact that $\mathrm{BM}$ aspiration does not allow to recover the Oct- $4^{+}$ tumor cells attached to the stroma. Oct- $4^{+}$cells from primary tumors and metastatic BM aspirates carried amplification of the MYCN oncogene or expressed the NB84 neuroblastic marker, respectively, and were located predominantly in perivascular areas and at a lower extent in perinecrotic areas, similarly to that reported recently for primary glioma [59].

To investigate the functional relationships between Oct $-4^{+}$NB cells and TECs, we set up an orthotopic NB model in immunodeficient mice using the HTLA-230 cell line. This model recapitulates the onset and progression of NB observed in patients. Orthotopic tumors contained a half of the EMs lined by $M Y C N$-amplified TECs. Oct $-4^{+}$cells showed a predominant perivascular distribution, with few of them homing in perinecrotic areas.

Hypoxia plays a critical role in the establishment of niches where cancer stem cells home and maintain stemness and self-renewal [60]. It has been recently shown 
that the perinecrotic niche in gliomas is strongly hypoxic (approximately 1\% oxygen tension) and this microenvironment may promote HIF- $2 \alpha$-dependent reprogramming of non-stem tumor cells towards a cancer stem celllike phenotype [61]. Previously it was shown that in NB biopsy specimens HIF-2 $\alpha$ marks a perivascular niche containing cells that express neural crest markers [35], and that HIF- $2 \alpha$ maintains an undifferentiated state in NB tumor-initiating cells [22]. HIF-2 $\alpha$ regulates Oct-4 gene expression [40] and we identified Oct $-4^{+} \mathrm{NB}$ cells co-expressing HIF- $2 \alpha$ in perivascular areas, consistent with the results of Pietras et al [35]. In addition, we have reported for the first time the existence of a perinecrotic putative niche in human NB where scanty Oct- $4^{+}$cells home. The relations between Oct- $4^{+}$cells present at the latter site and those found in perivascular areas are so far unknown, but it is tempting to speculate that the perinecrotic Oct- $4^{+}$NB cells are more stem-like cells than the perivascular ones, which have moved to a less hypoxic area and may be prone to differentiation. On the other hand, perivascular Oct $-4^{+}$cells can migrate back to the perinecrotic putative niche and revert to a cancer-stem cell-like phenotype likely through epigenetic mechanisms [62]. In this respect, the possibility that TECs can de-differentiate back to progenitor state under the influence of stimuli like hypoxia cannot be excluded and warrants further investigation.

TNC is involved in CNS embryogenesis, especially in the formation of neural stem cell niches [27-29]. TNC expression, which is under the control of Oct-4 [62], is low in normal brain tissue and upregulated in several malignant brain tumors in association with increased vascularity, short time to relapse, and poor prognosis [26, 63]. Little information was so far available on TNC expression in human NB.

We found that all perivascular Oct- $4^{+} \mathrm{NB}$ cells in primary and ortothopic tumors co-expressed surface TNC that was absent in either perinecrotic Oct- $4^{+}$cells or bulk tumor cells. $\mathrm{TNC}^{+} /$Oct $-4^{+} \mathrm{NB}$ cells were detected consistently in close proximity or adherent to the EM wall, suggesting that ECs regulate $\mathrm{TNC}^{+} / \mathrm{Oct}-4^{+}$cell viability and self-renewal $[28,64]$. $\mathrm{TNC}^{+} / \mathrm{Oct}-4^{+}$perivascular tumor cells from orthotopic tumors were found to express SOX-2, CD133, HIF-2 $\alpha$, CD24, VEGF-R2, $\beta$ III tubulin, c-kit and nestin, as well as GD2, CD56 and NB84. SOX-2, as Oct-4, maintains self-renewal of undifferentiated embryonic stem cells [12-14]. CD133, $\beta$ III tubulin, c-kit and nestin are expressed by NB progenitor cells [15, 46-48]. CD24 identifies a tumor-initiating cell population in BM metastatic NB, and NB84 has been detected in neurospheres thereof [65]. Besides being neuroblastic markers, CD56 [66] is expressed by immature and TECs, and GD2 by mesenchymal stem cells [67].

The overall immunophenotypic profile of $\mathrm{TNC}^{+} /$Oct -4 perivascular NB cells was consistent with their progenitor cell nature. Accordingly, these cells showed high plasticity both in vitro and in vivo. Thus, $\mathrm{TNC}^{+} / \mathrm{Oct}-4^{+}$ cells grew as neurospheres in vitro for many passages, a feature typical of tumor stem/progenitor cells [35, 68]. These neurospheres expressed stem cell-related markers such as $\beta$ III-tubulin, HIF- $2 \alpha$, nestin and Notch-2, which controls TNC expression and angiogenesis [69]. Three lines of evidence demonstrated unambiguously that $\mathrm{TNC}^{+} / \mathrm{Oct}-4^{+}$cells were the progenitors of NBderived ECs, and namely (i) in vitro these cells, but not their $\mathrm{TNC}^{-}$counterparts, differentiated into endotheliallike cells expressing VE-cadherin, PSMA and to a lesser extent CD31 after culture with VEGF, and (ii) in vivo $\mathrm{TNC}^{+}$, but not $\mathrm{TNC}^{-}$HTLA-230 cells, formed ortothopic tumors in which a half of the EMs were lined by NB-derived ECs. However, both $\mathrm{TNC}^{+}$and $\mathrm{TNC}^{-}$cell fractions were tumorigenic, pointing to the progenitor rather than cancer stem cell nature of $\mathrm{TNC}^{+} / \mathrm{Oct}-4^{+}$cells. (iii) In vivo the $\mathrm{TNC}^{-} / \mathrm{Oct}^{-} 4^{-}$GI-LI-N NB cell line formed orthotopic tumors completely devoid of TECs lined by TECs.

The virtually ubiquitous detection of $\mathrm{TNC}^{+} / \mathrm{Oct}-4^{+}$ TEC progenitor cells in primary tumors is in apparent disagreement with the previous demonstration that only one-third of primary NB samples contained TECs [8]. It is conceivable that unknown micro-environmental factors influence in the individual cases the ability of $\mathrm{TNC}^{+} /$ Oct $-4^{+}$NB cells to generate tumor-derived EM. A possible factor is the scanty distribution of hypoxic areas in tumors where Oct- $4^{+}$side-population NB cells have been shown to migrate in vivo [70,71]. Notably, in this respect, we observed that TECs lining the EM tended to concentrate in the tumor core where oxygen tension is very low.

In conclusion, we have identified in primary and ortothopic NB tumors two putative niches containing Oct $-4^{+}$tumor cells and shown that surface TNC allows to dissect these Oct- $4^{+}$cell subsets. Oct $-4^{+} / \mathrm{TNC}^{+}$perivascular NB cells displayed a high degree of plasticity and served as progenitors of TECs. Therapeutic targeting of $\mathrm{Oct}^{+} / \mathrm{TNC}^{+}$progenitors may counteract the contribution of NB-derived ECs to tumor relapse and chemoresistance.

\section{Materials and Methods}

\section{Patients}

Tumors from 23 NB patients as well as 10 metastatic BM aspirates were studied. Six patients had stage 1 disease, 5 stage 2, 3 stage $4 \mathrm{~s}$ and 19 stage 4 according to the International Neuroblasto- 
ma Staging System classification [72] (Table 1). All patients were tested at disease onset in the absence of any treatment. The study was approved by the local Ethics Committee.

\section{Immunofluorescence study}

Indirect immunofluorescence was performed on 4- $\mu \mathrm{m}$-thick formalin-fixed, paraffin-embedded or cryopreserved tissue sections or cytospins as previously described [8]. The following antibodies were used: anti-human(h)CD31 (diluted 1:50; Dako Cytomation, Hamburg, Germany), anti-mouse(m)CD34 (diluted 1:50; Novus Biologicals, Littleton, CO, USA), anti-human endoglin (CD105) (1:50; Dako), anti-alpha-smooth muscle actin ( $\alpha$-SMA; 1:50; Dako), anti-von Willebrand factor (vWF) (1:50; Dako), anti-VECadherin (1:50; Chemicon International, Millipore, Billerica, MA, USA), anti-GD2 (1:500; secreted from the hybridoma cell line 14.G2, a generous gift of RA Reisfeld, The Scripps Institute, La Jolla, CA, USA), anti-NB84 (1:100; Dako), anti-prostate-specific membrane antigen (1:50; anti-CB-PSMA) that detects specifically an epitope expressed by newly formed microvessels [73], antiHIF $1 \alpha$ (1:100; Novus Biologicals), anti-HIF2 $\alpha$ (1:100; Novus Biologicals), anti- $\beta$ III tubulin (1:50; Novus Biologicals), anti-CD24 (1:50; Novus Biologicals), anti-Oct-4 (1:50, Clone 10H11.2 that detects the Oct-4A isoform; Chemicon International, Millipore), anti-SOX-2 (1:50; Chemicon International), anti-Tenascin C (1:50; Clone CB-TNX; MediaPharma, Chieti, Italy), anti-nestin (1:50; Chemicon International), anti-CD117 (c-Kit) (1:100; Chemicon International), anti-CD271 (nerve growth factor receptor p75) (1:50; Chemicon International), anti-CD133 (1:50; Miltenyi Biotec Inc, Auburn CA, USA), anti-VEGF R2 (1:100; R\&D Systems Inc, Minneapolis, USA), anti-Notch2 (1:50; Abcam Inc), antiCD56 (1:50; Invitrogen Corp, Camarillo, CA, USA), anti-CD57 (1:50; Invitrogen Corp), and anti-Telomerase (1:100; LabVision, Fremont, CA, USA). Antigen retrieval slides were incubated with primary antibodies overnight at $4{ }^{\circ} \mathrm{C}$, followed by 30 -min incubation with secondary antibodies of the appropriate species conjugated with different fluorochromes (1:50; Dako). After washing, the slides were counterstained with DAPI and coverslipped. Results were photographically documented using a digital photo-device (Nikon Instruments, see below). Isotype-matched non-binding mAbs were used in all antibody-staining experiments to exclude non-specific reactivity.

\section{EM counts}

EM density was assessed by a combination of anti-hCD31 or anti-mCD34 staining and morphological analysis and examination of 20-50 microscopic fields $\left(0.5 \mathrm{~mm}^{2}\right)$ per tumor for a minimum of 500 cells counted. Tumor sections were examined under low magnification $(40 \times)$ to detect areas with high EM density and microvessels were counted in a representative high magnification $(100 \times)$ field in each area. The most intense vascular areas (hotspots) were selected subjectively from each tumor section as described by Weidner [74]. Sclerotic and necrotic areas were avoided. EM with a clearly defined lumen or well-defined linear vessel shape, but not single EC, was taken into account for EM counting.

\section{Fluorescent in situ hybridization (FISH)}

FISH was performed as described [8] using rhodamine-labeled $M Y C N$-specific DNA probe (QBIOgene Inc, Hamburg, Germany) and mouse Cot-1 DNA probe (Life Technologies Gibco BRL,
Paisley, Scotland).

\section{Image analysis}

Digital images were acquired using a Nikon E-1000 fluorescence microscope (Nikon Instruments, Tokyo, Japan) equipped with appropriate filter sets and the Genikon imaging system software (Nikon Instruments).

\section{In vivo experiments}

All procedures involving animals were performed in respect of the National and International current regulations (D.lvo 27/01/1992, no. 116, European Economic Community Council Directive 86/609, OJL 358, December 1, 1987). All procedures were reviewed and approved by the licensing and Ethical Committee of the National Cancer Research Institute, Genoa, Italy, and by the Italian Ministry of Health. Female Hsd athymic nude (nude/ nude) mice, 7-8 weeks old, were purchased from Harlan Laboratories (Harlan Italy, S Pietro al Natisone, Italy) and housed in sterile enclosures under specific pathogen-free conditions. In all experiments, mice were anesthetized with ketamine (Imalgene 1000, Merial Italia SpA., Milan, Italy), subjected to laparotomy and injected with HTLA-230 or GI-LI-N cells $\left(1.5 \times 10^{6}\right.$ cells in $20 \mu$ l of saline solution) in the capsule of the left adrenal gland, as previously described [42]. No mice died as a result of this treatment. Mice were sacrificed when signs of poor health became evident.

Finally, $\mathrm{TNC}^{+}$and $\mathrm{TNC}^{-}$cells $\left(1 \times 10^{5}\right.$ cells $)$ isolated from the HTLA-230 cell line (see below) were implanted in the capsule of the left adrenal gland of nude/nude mice (Harlan Laboratories, Indianapolis, Indiana, USA). In some experiments, groups of six mice each were injected with $\mathrm{TNC}^{+}$and $\mathrm{TNC}^{-}$cells and sacrificed at various times following cell inoculation $(7,14,21,28$ and 35 days) by cervical dislocation after being anesthetized with xilezine.

\section{Isolation and culture of TNC ${ }^{+}$and TNC HTLA-230 cells}

$\mathrm{TNC}^{+}$cells were isolated from the human HTLA-230 NB cell line by magnetic cell sorting using the anti-TNC CB-TNX mAb [75] and the MACS system (Miltenyi Biotec, Auburn, CA, USA). Briefly, cells were labeled with the anti-TNC mAb for $20 \mathrm{~min}$, then washed twice and suspended in MACS buffer (PBS supplemented with $1 \%$ BSA and $5 \mathrm{mM}$ EDTA). After washings, cells were separated into $\mathrm{TNC}^{+}$and $\mathrm{TNC}^{-}$fractions on a magnetic stainless steel wool column (Miltenyi Biotec), according to the manufacturer's recommendations. $\mathrm{TNC}^{-}$cells were subjected to a further round of depletion of residual $\mathrm{TNC}^{+}$cells using the same immunomagnetic procedure. At the end of the separation process, $\mathrm{TNC}^{+}$and $\mathrm{TNC}^{-}$ cell fractions were cytocentrifuged and stained by immunofluorescence with anti-TNC mAb. Higher than $98 \%$ of the $\mathrm{TNC}^{+}$cell fraction expressed $\mathrm{TNC}$, whereas the $\mathrm{TNC}^{-}$cell fraction contained less than $1 \%$ of $\mathrm{TNC}^{+}$cells.

To evaluate the ability of these cell fractions to grow in nonadhesive condition as floating spheres, cells were plated in serumfree DMEM-F12 (Invitrogen), supplemented with 2\% B27 (Invitrogen), $10 \mathrm{ng} / \mathrm{ml}$ basic fibroblast growth factor (bFGF) and $20 \mathrm{ng} /$ $\mathrm{ml}$ epidermal growth factor (EGF) (all from Sigma-Aldrich Corp., St Louis, MO, USA) [76].

In vitro formation of capillary-like structures was studied on cells seeded onto Matrigel-coated wells in culture medium (Tube Formation Kit, Trevigen Inc., Gaithersburg, MD, USA). $\mathrm{TNC}^{+}$and 
TNC $^{-}$HTLA-230 cells $\left(1-3 \times 10^{4}\right.$ cells/well $)$ were seeded onto Matrigel-coated wells in Endothelial Basal Medium without serum in the presence or absence of the angiogenesis mediators VEGF (5-15 ng/ml) and bFGF (20-50 ng/ml). Sulforaphane at 1-10 $\mu \mathrm{M}$ was added as a control inhibitor of tube formation. As positive control for this system, we used normal ECs isolated from human umbilical vein cells (HUVECs). Each experiment was repeated at least three times. Cell organization onto Matrigel was observed over a 2-24-h period with an inverted microscope with a $10 \times$ phase-contrast objective and experimental results were recorded.

To evaluate cell differentiation, $\mathrm{TNC}^{+}$and $\mathrm{TNC}^{-} \mathrm{HTLA}-230$ cells were incubated in EndoGRO-MV-VEGF complete media kit (Millipore) with VEGF ( $5 \mathrm{ng} / \mathrm{ml}$ ) on EC attachment factor (Roche) coated plates. The medium was changed twice a week for 3 weeks. Thereafter, cells were cytocentrifuged and stained by immunofluorescence for PSMA, VE-cadherin and CD31.

\section{Real-time $q P C R$}

mRNA was extracted from human NB cell lines HTLA-230 and GI-LI-N and human melanoma cell line MZ2-MEL [77] as positive control [51] using RNeasy Mini Kit from Qiagen (Qiagen $\mathrm{GmbH}$, Hilden, Germany) and subjected to RT-PCR. Briefly, 1 $\mu \mathrm{g}$ of RNA was reverse transcribed using the RevertAid ${ }^{\mathrm{TM}}$ First Strand cDNA Synthesis kit (Fermentas Inc., Burlington, ON, Canada) following the instructions of the manufacturer. In all, $5 \mu 1$ of cDNA was used in $25 \mu \mathrm{l}$ PCR reaction, using the $2 \times$ PCR Master Mix (Fermentas Inc.). The following oligonucleotide primer pairs were used at the indicated annealing temperature: TNC, forward 5'-GCAGCCACAGAGTTGGAC-3' and reverse 5'-GAGATCCTCTGTGACGACCT- $3{ }^{\prime}$ at $58{ }^{\circ} \mathrm{C}$ [28]; GAPDH, forward 5'-ACATCGCTCAGAACACCTATGG-3' and reverse 5'-GGGTCTACATGGCAACTGTGAG- $3^{\prime}$ at $60^{\circ} \mathrm{C}$. All reactions were carried out in epgradient S Mastercycler (Eppendorf, Hamburg, Germany) starting with a 2-min denaturation step at $94{ }^{\circ} \mathrm{C}$ followed by 35 cycles of $15 \mathrm{~s}$ at $94{ }^{\circ} \mathrm{C}, 30 \mathrm{~s}$ at the respective annealing temperature, and 70 -s elongation at $72{ }^{\circ} \mathrm{C}$. The reaction was followed by a 7 -min final elongation step at $72{ }^{\circ} \mathrm{C}$ and cooled down to $4{ }^{\circ} \mathrm{C}$. The PCR products were separated on a $1 \%$ agarose gel.

\section{Statistical analysis}

Analysis of quantitative data was performed by non-parametric repeated measurement analysis of variance (Friedman's test). Angular transformation was applied and regression analysis of transformed data was performed in some experiments [78]. To compare quantitative variables between two groups of observations, the non-parametric Mann-Whitney U test was used. Statistical significance of differences between experimental and control groups was determined by ANOVA with Tukey's multiple comparison test using GraphPad Prism 3.0 software (GraphPad Software, Inc.).

\section{Acknowledgments}

We thank the late Dr Giorgio Corte for reading the manuscript. Special thanks go to Dr Paolo Bianco for discussion and suggestions. This work was supported by Fondazione Italiana Neuroblastoma, Fondazione "Guido Berlucchi", Fondazione "Bianca e Wilma Querci", Progetto di Ricerca Regione Liguria "Endotelio di derivazione tumorale: caratterizzazione e targeting immunologico a fini terapeutici" and Ministero della Salute Progetto
Strategico Oncologico 2006 "Microambiente tumorale: ruolo nella progressione neoplastica sulle difese dell'ospite. Identificazione di nuovi bersagli per lo sviluppo di terapie innovative". CC was supported by Associazione Italiana per la Ricerca sul Cancro (AIRC).

\section{References}

1 Brodeur GM. Neuroblastoma: biological insights into a clinical enigma. Nat Rev Cancer 2003; 3:203-216.

2 Meitar D, Crawford SE, Rademaker AW, Cohn SL. Tumor angiogenesis correlates with metastatic disease, $N$-myc amplification, and poor outcome in human neuroblastoma. $J$ Clin Oncol 1996; 14:405-414.

3 Dhakal HP, Naume B, Synnestvedt M, et al. Vascularization in primary breast carcinomas: its prognostic significance and relationship with tumor cell dissemination. Clin Cancer Res 2008; 14:2341-2350.

4 Folkman J. Seminars in Medicine of the Beth Israel Hospital, Boston. Clinical applications of research on angiogenesis. $N$ Engl J Med 1995; 333:1757-1763.

5 Carmeliet P, Jain RK. Angiogenesis in cancer and other diseases. Nature 2000; 407:249-257.

6 Bergers G, Benjamin LE. Tumorigenesis and the angiogenic switch. Nat Rev Cancer 2003; 3:401-410.

7 Hendrix MJ, Seftor EA, Hess AR, Seftor RE. Vasculogenic mimicry and tumor-cell plasticity: lessons from melanoma. Nat Rev Cancer 2003; 3:411-421.

8 Pezzolo A, Parodi F, Corrias MV, Cinti R, Gambini C, Pistoia $\mathrm{V}$. Tumor origin of endothelial cells in human neuroblastoma. J Clin Oncol 2007; 25:376-383.

9 Bussolati B, Grange C, Sapino A, Camussi G. Endothelial cell differentiation of human breast tumor stem/progenitor cells. $J$ Cell Mol Med 2009; 13:309-319.

10 Ribatti D, Nico B, Pezzolo A, et al. Angiogenesis in a human neuroblastoma xenograft model: mechanisms and inhibition by tumor-derived interferon-gamma. Br J Cancer 2006; 94:1845-1852.

11 Shen R, Ye Y, Chen L, Yan Q, Barsky SH, Gao JX. Precancerous stem cells can serve as tumor vasculogenic progenitors. PLoS One 2008; 3:e1652.

12 Boyer LA, Lee TI, Cole MF, et al. Core transcriptional regulatory circuitry in human embryonic stem cells. Cell 2005; 122:947-956.

13 Kim JB, Sebastiano V, Wu G, et al. Oct-4 induced pluripotency in adult neural stem cells. Cell 2009; 136:411-419.

14 Babaie Y, Herwig R, Greber B, et al. Analysis of Oct4dependent transcriptional networks regulating self-renewal and pluripotency in human embryonic stem cells. Stem Cells 2007; 25:500-510.

15 Chen YC, Hsu HS, Chen YW, et al. Oct-4 expression maintained cancer stem-like properties in lung cancer-derived CD133-positive cells. PLoS One 2008; 3:e2637.

16 Gidekel S, Pizov G, Bergman Y, Pikarsky E. Oct-3/4 is a dose-dependent oncogenic fate determinant. Cancer Cell 2003; 4:361-370.

17 Levina V, Marrangoni AM, DeMarco R, Gorelik E, Lokshin AE. Drug-selected human lung cancer stem cells: cytokine network, tumorigenic and metastatic properties. PLoS One 2008; 3:e3077. 
18 Huang D, Gao Q, Guo L, et al. Isolation and identification of cancer stem-like cells in esophageal carcinoma cell lines. Stem Cells Dev 2009; 18:465-473.

19 Chiou SH, Yu CC, Huang CY, et al. Positive correlations of Oct-4 and Nanog in oral cancer stem-like cells and highgrade oral squamous cell carcinoma. Clin Cancer Res 2008; 14:4085-4095.

20 Das B, Tsuchida R, Malkin D, Koren G, Baruchel S, Yeger H. Hypoxia enhances tumor stemness by increasing the invasive and tumorigenic side population fraction. Stem Cells 2008; 26:1818-1830.

21 Takahashi K, Tanabe K, Ohnuki M, et al. Induction of pluripotent stem cells from adult human fibroblasts by defined factors. Cell 2007; 131:861-872.

22 Pietras A, Hansford LM, Johnsson AS, et al. HIF-2 $\alpha$ maintains an undifferentiated state in neural crest-like human neuroblastoma tumor-initiating cells. Proc Natl Acad Sci USA 2009; 106:16805-16810.

23 Orend G. Potential oncogenic action of tenascin-C in tumorigenesis. Int J Biochem Cell Biol 2005; 37:1066-1083.

24 Hirata E, Arakawa Y, Shirahata M, et al. Endogenous tenascin-C enhances glioblastoma invasion with reactive change of surrounding brain tissue. Cancer Sci 2009; 100:1451-1459.

25 Zagzag D, Friedlander DR, Miller DC, et al. Tenascin expression in astrocytomas correlates with angiogenesis. Cancer Res 1995; 55:907-914.

26 Puget S, Grill J, Valent A, et al. Candidate genes on chromosome 9q33-34 involved in the progression of childhood ependymomas. J Clin Oncol 2009; 27:1884-1892.

27 Garcion E, Halilagic A, Faissner A, ffrench-Constant C. Generation of an environmental niche for neural stem cell development by the extracellular matrix molecule tenascin C. Development 2004; 131:3423-3432.

28 von Holst A, Egbers U, Prochiantz A, Faissner A. Neural stem/progenitor cells express 20 tenascin $\mathrm{C}$ isoforms that are differentially regulated by Pax6. J Biol Chem 2007; 282:91729181.

29 von Holst A. Tenascin C in stem cell niches: redundant, permissive or instructive? Cells Tissues Organs 2008; 188:170177.

30 Atlasi Y, Mowla SJ, Ziaee SA, et al. OCT4 spliced variants are differentially expressed in human pluripotent and nonpluripotent cells. Stem Cells 2008; 26:3068-3074.

31 Wang X, Zhao Y, Xiao Z, et al. Alternative translation of OCT4 by an internal ribosome entry site and its novel function in stress response. Stem Cells 2009; 27:1265-1275.

32 Wilson A, Trumpp A. Bone-marrow haematopoietic-stem-cell niches. Nat Rev Immunol 2006; 6:93-106.

33 Sacchetti B, Funari A, Michienzi S, et al. Self-renewing osteoprogenitors in bone marrow sinusoids can organize a hematopoietic microenvironment. Cell 2007; 133:928-939.

34 Calabrese C, Poppleton H, Kocak M, et al. A perivascular niche for brain tumor stem cells. Cancer Cell 2007; 11:69-82.

35 Pietras A, Gisselsson D, Ora I, et al. High levels of HIF-2 $\alpha$ highlight an immature neural crest-like neuroblastoma cell cohort located in a perivascular niche. J Pathol 2008; 214:482488.

36 Tai MH, Chang CC, Kiupel M, Webster JD, Olson LK, Trosko JE. Oct-4 expression in adult human stem cells: evidence in support of the stem cell theory of carcinogenesis. Carcinogenesis 2005; 26:495-502.

37 Atlasi Y, Mowla SJ, Ziaee SA, Bahrami AR. OCT-4, an embryonic stem cell marker, is highly expressed in bladder cancer. Int J Cancer 2007; 120:1598-1602.

38 Sotomayor P, Godoy A, Smith GJ, Huss WJ. Oct4A is expressed by a subpopulation of prostate neuroendocrine cells. Prostate 2009; 69:401-410.

39 Karoubi G, Cortes-Dericks L, Gugger M, Galetta D, Spaggiari L, Schmid RA. Atypical expression and distribution of embryonic stem cell marker, OCT4, in human lung adenocarcinoma. J Surg Oncol 2010; 102:689-698.

40 Covello KL, Kehler J, Yu H, et al. HIF-2 $\alpha$ regulates Oct-4: effects of hypoxia on stem cell function, embryonic development, and tumor growth. Genes Dev 2006; 20:557-570.

41 Miettinen M, Chatten J, Paetau A, Stevenson A. Monoclonal antibody NB84 in the differential diagnosis of neuroblastoma and other small round cell tumors. Am J Surg Pathol 1998; 22:327-332.

42 Brignole C, Marimpietri D, Pastorino F, et al. Effect of bortezomib on human neuroblastoma cell growth, apoptosis, and angiogenesis. J Natl Cancer Inst 2006; 98:1142-1157.

43 Krams M, Hero B, Berthold F, Parwaresch R, Harms D, Rudolph P. Full-length telomerase reverse transcriptase messenger RNA is an independent prognostic factor in neuroblastoma. Am J Pathol 2003; 162:1019-1026.

44 Lim SC. CD24 and human carcinoma: tumor biological aspect. Biomed Pharmacother 2005; 59:S351-S354.

45 Bunone G, Mariotti A, Compagni A, Moranti E, Della Valle G. Induction of apoptosis by $\mathrm{p} 75$ neurotrophin receptor in human neuroblastoma cells. Oncogene 1997; 14:1463-1470.

46 Prasannan L, Misek DE, Hinderer R, Michon J, Geiger JD, Hanash SM. Identification of beta-tubulin isoforms as tumor antigens in neuroblastoma. Clin Cancer Res 2000; 6:39493956.

47 Uccini S, Mannarino O, McDowell HP, et al. Clinical and molecular evidence for c-kit receptor as a therapeutic target in neuroblastic tumors. Clin Cancer Res 2005; 11:380-390.

48 Thomas SK, Messam CA, Spengler BA, Biedler JL, Ross RA. Nestin is a potential mediator of malignancy in human neuroblastoma cells. J Biol Chem 2004; 279:27994-27999.

49 Saito M, Yu RK, Cheung NK. Ganglioside GD2 specificity of monoclonal antibodies to human neuroblastoma cell. Biochem Biophys Res Commun 1985; 127:1-7.

50 Wachowiak R, Rawnaq T, Metzger R, et al. Universal expression of cell adhesion molecule NCAM in neuroblastoma in contrast to L1: implications for different roles in tumor biology of neuroblastoma? Pediatr Surg Int 2008; 24:1361-1364.

51 Fukunaga-Kalabis M, Martinez G, Nguyen TK, et al. Tenascin-C promotes melanoma progression by maintaining the ABCB5-positive side population. Oncogene 2010; 29:6115-6124.

52 Mhawech-Fauceglia P, Zhang S, Terracciano L, et al. Prostate specific membrane antigen (PSMA) protein expression in normal and neoplastic tissues and its sensitivity and specificity in prostate adenocarcinoma: an immunohistochemical study using multiple tumor tissue microarray technique. Histopathology 2007; 50:472-483.

53 Bussolati B, Deregibus MC, Camussi G. Characterization of 
molecular and functional alterations of tumor endothelial cells to design anti-angiogenic strategies. Curr Vasc Pharmacol 2010; 8:220-232

54 Carosella ED, Favier B, Rouas-Freiss N, Moreau P, Lemaoult $\mathrm{J}$. Beyond the increasing complexity of the immunomodulatory HLA-G molecule. Blood 2008; 111:4862-4870.

55 Solecki DJ, Liu XL, Tomoda T, Fang Y, Hatten ME. Activated Notch2 signaling inhibits differentiation of cerebellar granule neuron precursors by maintaining proliferation. Neuron 2001; 31:557-568.

56 Bussolati B, Bruno S, Grange C, Ferrando U, Camussi G. Identification of a tumor-initiating stem cell population in human renal carcinomas. FASEB J 2008; 22:3696-3705.

57 Alvero AB, Fu HH, Holmberg J, et al. Stem-like ovarian cancer cells can serve as tumor vascular progenitors. Stem Cells 2009; 27:2405-2413.

58 Ricci-Vitiani L, Pallini R, Biffoni M, et al. Tumor vascularization via endothelial differentiation of glioblastoma stemlike cells. Nature 2010; 468:824-828.

59 Seidel S, Garvalov BK, Wirta V, et al. A hypoxic niche regulates glioblastoma stem cells through hypoxia inducible factor 2 alpha. Brain 2010; 133:983-995.

60 Heddleston JM, Li Z, Lathia JD, Bao S, Hjelmeland AB, Rich JN. Hypoxia inducible factors in cancer stem cells. $\mathrm{Br} J \mathrm{Can}-$ cer 2010; 102:789-795.

61 Heddleston JM, Li Z, McLendon RE, Hjelmeland AB, Rich $\mathrm{JN}$. The hypoxic microenvironment maintains glioblastoma stem cells and promotes reprogramming towards a cancer stem cell phenotype. Cell Cycle 2009; 8:3274-3284.

62 Jung M, Peterson H, Chavez L, et al. A data integration approach to mapping OCT4 gene regulatory networks operative in embryonic stem cells and embryonal carcinoma cells. PLoS One 2010; 5:e10709.

63 Godard S, Getz G, Delorenzi M, et al. Classification of human astrocytic gliomas on the basis of gene expression: a correlated group of genes with angiogenic activity emerges as a strong predictor of subtypes. Cancer Res 2003; 63:66136625 .

64 Butler JM, Nolan DJ, Vertes EL, et al. Endothelial cells are essential for the self-renewal and repopulation of Notchdependent hematopoietic stem cells. Cell Stem Cell 2010; 6:251-264.

65 Hansford LM, McKee AE, Zhang L, et al. Neuroblastoma cells isolated from bone marrow metastases contain a naturally enriched tumor-initiating cell. Cancer Res 2007; 67:1123411243.
66 Bozzi F, Collini P, Aiello A, et al. Flow cytometric phenotype of rhabdomyosarcoma bone marrow metastatic cells and its implication in differential diagnosis with neuroblastoma. Anticancer Res 2008; 28:1565-1569.

67 Martinez C, Hofmann TJ, Marino R, Dominici M, Horwitz EM. Human bone marrow mesenchymal stromal cells express the neural ganglioside GD2: a novel surface marker for the identification of MSCs. Blood 2007; 109:4245-4248.

68 Al-Hajj M, Clarke MF. Self-renewal and solid tumor stem cells. Oncogene 2004; 23:7274-7282.

69 Sivasankaran B, Degen M, Ghaffari A, et al. ChiquetEhrismann R, Boulay JL. Tenascin-C is a novel RBP Jkappainduced target gene for Notch signaling in gliomas. Cancer Res 2009; 69:458-465.

70 Mahller YY, Williams JP, Baird WH, et al. Neuroblastoma cell lines contain pluripotent tumor initiating cells that are susceptible to a targeted oncolytic virus. PLoS One 2009; 4:e4235.

71 Marzi I, D'Amico M, Biagiotti T, et al. Purging of the neuroblastoma stem cell compartment and tumor regression on exposure to hypoxia or cytotoxic treatment. Cancer Res 2007; 6:2402-2407.

72 Brodeur GM, Pritchard J, Berthold F, et al. Revisions of the international criteria for neuroblastoma diagnosis, staging, and response to treatment. J Clin Oncol 1993; 11:1466-1477.

73 Malavasi F, Deaglio S, Zaccarello G, et al. The hidden life of NAD+-consuming ectoenzymes in the endocrine system. $J$ Mol Endocrinol 2010; 45:183-191.

74 Weidner N. Current pathologic methods for measuring intratumoral micro-vessel density within breast carcinoma and other solid tumors. Breast Cancer Res Treat 1995; 36:169180 .

75 Davico Bonino L, De Monte LB, Spagnoli GC, et al. Bispecific monoclonal antibody anti-CD3 x anti-tenascin: an immunotherapeutic agent for human glioma. Int J Cancer 1995; 61:509-515.

76 Vescovi AL, Galli R, Reynolds BA. Brain tumor stem cells. Nature Rev 2006; 6:425-436.

77 Loriot A, De Plaen E, Boon T, De Smet C. Transient downregulation of DNMT1 methyltransferase leads to activation and stable hypomethylation of MAGE-A1 in melanoma cells. J Biol Chem 2006; 281:10118-10126.

78 Sokal RR, Rohlf FJ. The principle and practice of statistics in biological research. In: Freeman WH, ed. Biometry. New York: Academic Press, 1981:40-58.

(Supplementary information is linked to the online version of the paper on the Cell Research website.) 